\begin{tabular}{c}
\hline Review of \\
ECONOMICS \\
and \\
INSTITUTIONS
\end{tabular}

\title{
Labor Market Institutions and Their Impact on Shadow Economies in Europe
}

\author{
Kamila Fialová \\ Academy of Science of the Czech Republic
}

\author{
Ondrej Schneider \\ Charles University in Prague
}

\begin{abstract}
This paper analyzes the role of labor market institutions in explaining the development of the shadow economies in European countries. We use several alternative measures of the shadow sector to examine the effects of labor market institutions in two specific regions, the old and the new European Union member states. Comparing alternative measures of the shadow sector allows a more granulated analysis of the effects of labor market institutions. Our results indicate that the institution that unambiguously increases the shadow economy is the strictness of employment protection legislation. Other labor market institutions have less straightforward and statistically robust effects, and their impact often differs between the old and new EU member states.
\end{abstract}

JEL classification: J08; 017; 052;

Keywords: labor market institutions, shadow economy, shadow employment, European Union

This paper is a background paper for "In from the Shadow: Integrating Europe's Informal Labor", a World Bank regional report on the informal sector in Central, Southern Europe and the Baltic countries (Task number P112988) conducted by the Human Development Economics Group, in the World Bank's Regional Office for Europe and Central Asia. The work was also supported by Grant No. 14-15008S of the Grant Agency of the Czech Republic under project 'Changing work and job values in the Czech Republic in a comparative perspective'. The authors are grateful to IZA's program area "Labor markets in emerging and transition economies" for providing data (http://www.iza.org /en/webcontent/research/ra5). The authors wish to thank Truman Packard, Johannes Koettl and Claudio Montenegro for their comments and help with supplying data.

\footnotetext{
$\square$ Corresponding Author. Address: Institute of Sociology, Academy of Science of the Czech Republic, Jilská 1 - 11000 Praha 1 (Phone: +420 210310 232. Email: kamila.fialova@soc.cas.cz).
}

\section{Recommended Citation}

Fialová, K., Schneider, O. (2014). Labor Market Institutions and Their Impact on Shadow Economies in Europe. Review of Economics and Institutions, 5(1), Article 3. doi: 10.5202/rei.v5i1.146. Retrieved from http://www.rei.unipg.it/rei/article/view/146 


\section{Introduction}

The shadow economy covers a wide range of activities that are, by definition, uneasy to observe and measure. Consequently, there are many definitions of the shadow economy. $\left.\right|_{1} ^{1}$ In our paper, the following definition is used in accordance with the European Commission (EC, 2004), OECD (OECD, 2004) or related research (for instance Schneider et al., 2010a): the shadow economy covers production of goods and services that is lawful by its nature, but is intentionally not declared to the public authorities. Thus, this definition excludes not only illegal activities, but also household production.

The shadow economy and informal labor markets are closely connected: by its very definition, any activity in the shadow economy involves informal labor market to some degree ${ }^{2}$ Individuals may be either excluded from the formal labor market by lack of opportunities, or exit the formal sector voluntarily because of both monetary and non-monetary benefits of informality. These two motives may be considered complementary, with different emphasis in different social and economic environments. According to Perry et al. (2007), the voluntary exit motive is mainly associated with independent workers acting as self-employed, while involuntary exclusion from formal labor market is mostly linked with salaried employees in Latin America and the Caribbean. Usually, the exclusion motive is perceived far less important in developed countries (see Oviedo et al., 2009). Fleeing into the shadow economy might have several motives, from avoiding payment of taxes and social security contributions, to avoiding complying with labor market, environmental or other standards and administrative procedures. Furthermore, the phenomenon has many dimensions, from full non-compliance and non-reporting of employment or business activities, to under-reporting of employment, wages etc.

There are many important negative consequences and costs of the shadow economy: revenue losses in form of taxes and social security contributions necessitating extra burden on formal workers; deficient protection of informal workers by labor standards and social protection system; lower productivity of informal firms due to their small size, restricted access to capital, technologies and markets, no legal enforcement of contracts and property rights, etc. ${ }^{3}$ unfair competition; overutilization of public goods and services

1 For a broader discussion of the definition of the shadow economy, see e.g., Thomas (1992), Pedersen (2003), Enste (2003) or OECD (2004).

2 Informal work can take many forms, from a second job together with a regular employment to non-participation in formal labor market. For a discussion on this topic see Schneider (2003).

3 In contrast, Schneider (2003) argues that informal sector exhibits higher level of productivity compared to the official economy. One of the reasons he mentions is a stronger work effort of informal workers, whose pay is not burdened by huge taxes, social contributions and other regulations. 
by informal sector not contributing to public budgets. In a broader perspective, the shadow economy might distort efficient allocation of resources, reduce the potential for economic growth and undermine social cohesion and legitimacy of the state ${ }^{4}$ For a detailed overview of the consequences of the shadow economy on economic performance see for instance Schneider and Enste (2000).

The European Union has been concerned with the shadow economy phenomena since the late 1990s and has developed a strategy to combat undeclared work (even listed as one of the goals of the Lisbon agenda). In its study, the European Commission (EC, 2004) pays a special attention to the group of new member states and candidate countries, where informality has a slightly different character given the previous era of centralized economies and the subsequent transformation induced by large institutional, economic and societal changes. Indeed, marked differences exist between the size of the shadow economy between the old and new European Union member states..$^{5}$ While the share of the shadow economy on GDP averaged around $27.5 \%$ in the new member states between 1999 and 2007, the corresponding share in the old member states stood at $17.9 \%$ only.

The shadow economy has a complex nature, determined by numerous economic, institutional, regulatory, social and cultural factors. These factors in general affect both individuals and firms' decision to stay formal or turn informal. In our research, we focus on labor market institutions, as these have been considered in earlier research as one of the main forces driving economic agents to informality (see e.g., Schneider and Enste, 2000, OECD, 2004, Oviedo et al., 2009). The institutional framework differs substantially across the European countries, although some convergence has been observed recently (see Fialová and Schneider, 2009).

In this paper, we present a cross-country econometric analysis of the impact of labor market institutions and institutional reforms on the size of shadow economies in European countries and study their main trends over the period 2000-2007. We analyze changes in labor market institutions and their impact on the share of labor force in the shadow employment and on the size of the shadow production. Furthermore, we address the differences between the old EU members and new member states (hereafter "NMS").

Our results indicate that the strictness of employment protection legislation unambiguously increases the shadow economy production and employment. The effects of other hereby examined labor market institutions,

${ }^{4}$ For a detailed survey of costs and benefits considered by individuals and firms in decision-making about turning informal, see Djankov et al. (2003).

5 For the purpose of this paper, we consider as old EU countries Belgium, Denmark, Germany, Greece, Spain, France, Ireland, Italy, Luxembourg, the Netherlands, Austria, Portugal, Finland, Sweden, the United Kingdom and non-EU Norway (sixteen countries). New member states ("NMS") are those countries acceding to the EU in 2004 and 2007: Bulgaria, Czech Republic, Cyprus, Estonia, Hungary, Latvia, Lithuania, Malta, Poland, Slovakia, Slovenia, Romania. 
i.e. active and passive labor market policies, labor taxation, trade union density and the minimum wage setting, tend to be less straightforward and statistically robust, and their impact sometimes differs between the old and new EU member states.

The paper is organized as follows. In the second section, we briefly sketch the development of the shadow economy in European countries and compare the old and new EU members. The next section describes the main factors driving economic subjects to informality, and discusses the major institutional factors influencing the development of the shadow economy. The fourth section describes the data and methodology. The fifth section then summarizes the key findings of our analysis. The last section concludes and discusses limitations of our research.

\section{The Shadow Economy in Europe}

Given the large heterogeneity in the motives for entering the shadow market and the difficulty to identify the large number of phenomena that the shadow economy might cover, it is extremely difficult to measure the scope of the shadow economy across different countries. Generally, there are three approaches to measuring the shadow economy: direct methods, indirect methods and model approaches. For a detailed discussion on the advantages and disadvantages of different estimation methods see Schneider and Enste (2000), Oviedo et al. (2009) or Perry et al. (2007). Our analysis relies on different data sources and adopts two comprehensive sets of indicators for the shadow economy in European countries. ${ }^{6}$

We first use the shadow production, i.e. the estimated share of the shadow economy on official GDP. The source of the data is Schneider et al. (2010a) who provides a unique database on the size and trends of the shadow economy for 162 countries between 1999 and 2006/2007. The estimation is based on a Multiple Indicators Multiple Causes (MIMIC) model approach. The clear advantage of this dataset is the use of a unified methodology and the broadness of the sample, explaining why many other studies use such data (see e.g., Loayza et al., 2005, Perry et al., 2007). Nevertheless, this approach has also considerable shortcomings and the data should be considered with caution. The main concern is the theoretical background of the relation between the shadow economy and its determinants, and the issue of causality that might be subject to discussion. However, although other data sources may present other valuable characteristics, providing a different overview on the extent of the shadow economy, we believe that the unified methodology underlying the data by Schneider et al. (2010a) offers an opportunity to consistently study the differences among countries and their development over time. For a comparison of different methods see Schneider and Enste

\footnotetext{
$\overline{6 \text { Summary statistics are given in Annex } 1 .}$
} 
(2000).

The second set of indicators that we use is the shadow employment, defined as the share of labor force in unregulated self- and wage-employment. This variable is estimated in four different ways using various sources from Eurostat. Firstly, we use an indicator from the household survey European Union-Statistics on Income and Living Conditions (EU-SILC), consisting in the share of the labor force not contributing to the pension system (both private and public), adjusted for the unemployment rate.7 Yet, this variable, which is available for 2007, offers only a very rough picture of the shadow employment and, in addition, the reliability of the information is rather questionable $\left.\right|^{8}$ Moreover, by comparing this variable with the aforementioned indicator of shadow production, substantial differences between these two data sets have been uncovered (see Annex 1). Secondly, we use three other proxies for shadow employment based on data from the Labor Force Survey (LFS), The first is the share of the labor force from small firms with less than ten employees, while the second one is the share of selfemployed. These two groups of workers are supposedly more exposed to shadow employment (Perry et al., 2007); however, the link is not necessarily as straightforward and intense in all countries. Again, these variables are available for 2006-2007 only. The third proxy is the share of "workers without a contract" on labor force, which is available since 2001. A shortcoming of this variable is that it combines both workers on temporary legal contracts and workers without a written contract. ${ }^{9}$ In other words, it covers both those who are indeed employed in the shadow economy, and those who are legally employed on a temporary basis. 10

Clearly, none of the proxies for the shadow employment is ideal for the purposes of our analysis, and then we use them for robustness checks. Given the abovementioned deficiencies of the indicators on shadow employment, descriptive analysis in the remainder of this section will mostly be based on shadow production.

7 The adjustment for the unemployment rate makes this variable methodologically comparable to the other indicators of shadow employment that we use in our analysis. Furthermore, this approach relies on the implicit assumption that the unemployed are not engaged in the informal sector.

8 Some cases needed to be deleted due to evident inconsistencies regarding development in time or comparison with similar countries.

9 OECD (2002) shows that temporary employment is concentrated among younger and less educated workers, as well as among workers employed in low-skill occupations, agriculture and small firms. These are also categories more prone to informal behavior.

${ }^{10}$ It is presumed that "contract" is only for formally contracted employees with an openended position. This, of course, disregards those who are contracted legally on a temporary or term appointment basis. This limitation might have been overcome with a sort of dummy variable that would control for whether countries allow temporary contracts or not. However, as indicated by OECD (2002), temporary work is an important feature of the employment legislation in most OECD European countries and, hence, there is no sufficient variation across countries' labor regulation on this matter for further investigation of this issue. 
Generally, Europe ranks rather low on the informality scale. According to Schneider et al. (2010a), the average size of the shadow economy was $34.0 \%$ of GDP in eighty-four developing countries in 2007, 32.6\% in twenty Eastern-European and Central-Asian transition countries and 16.6\% in twenty-five OECD countries. In 2007 the average for twenty-eight selected European countries examined in this paper was $21.1 \%$, with $25.9 \%$ in the NMS group and $17.4 \%$ in the old European countries. Yet, large differences among countries persist.

Heterogeneity in the old European countries group is stable: in 19992007, the coefficient of variation hovered around 30\% without any clear trend. In the NMS, the heterogeneity of the shadow economy was substantially lower throughout the examined period, with a moderate decreasing trend between 1999 and 2004 when the coefficient of variation fell from $20.4 \%$ to $18.8 \%$ and subsequently fluctuated around $19 \%$. Thus heterogeneity within this group has been mildly reduced, and so have been the differences between the old and new member states, as proved by Table 1 and Figure 1: the gap between the average values of these two groups shrank from 9.9 to 8.4 percentage points between 1999 and 2007, with a local peak in 2000 (10.3 percentage points). The share of the shadow economy is decreasing in the most recent years in the entire sample, with a slightly faster dynamics in the NMS group. Moreover, while the old European countries experienced the major drop at the beginning of the examined period, the NMS group recorded the largest reduction at the end of the time span.

Figure 1 sheds light on the evolution of the informal economy showing the change in the size of the shadow economy between 1999-2001 and 20052007 , on average. Albeit negligible (0.4 percentage points), the only country with an increase in the share of shadow production was Portugal. In contrast, the largest shadow economies (the Baltics, Bulgaria, Romania, Greece etc.) shrank the most. A significant reduction in the shadow economy was generally recorded in all the new member states.

\section{Labor Market Institutions and other Factors In- fluencing the Shadow Economy}

The development and the extent of the shadow economy are the result of a complex interplay among factors which vary across countries. The degree of economic development is often considered one of the most important factors, as less developed countries tend to have larger informal sectors (see Perry et al., 2007) 11

\footnotetext{
${ }^{11}$ In addition to general drivers of the shadow economy, some other factors may be important, such as macroeconomic policies, demographic and structural factors, etc. Given the level of development of the old member states and the fact that main transformation changes in the new member economies took place during the 1990s, these effects shall not be considered for our sample of EU countries.
} 
Table 1 - The Shadow Economy in Europe: \% of GDP, 1999-2007

\begin{tabular}{lrrr}
\hline \hline & $\mathbf{1 9 9 9 - 2 0 0 1}$ & $\mathbf{2 0 0 2 - 2 0 0 4}$ & $\mathbf{2 0 0 5 - 2 0 0 7}$ \\
\hline Austria & 9.8 & 9.8 & 9.6 \\
Belgium & 22.3 & 21.9 & 21.5 \\
Bulgaria & 36.9 & 35.5 & 33.4 \\
Cyprus & 28.7 & 28.0 & 27.2 \\
Czech Republic & 19.1 & 18.6 & 17.4 \\
Denmark & 18.1 & 17.9 & 17.2 \\
Estonia & 32.6 & 31.5 & 29.9 \\
Finland & 18.1 & 17.7 & 17.2 \\
France & 15.3 & 15.0 & 14.8 \\
Germany & 16.1 & 16.2 & 15.6 \\
Greece & 28.5 & 27.5 & 26.6 \\
Hungary & 25.1 & 24.3 & 23.8 \\
Ireland & 16.0 & 15.9 & 15.5 \\
Italy & 27.2 & 26.9 & 26.9 \\
Latvia & 30.5 & 29.4 & 27.8 \\
Lithuania & 33.6 & 32.2 & 30.4 \\
Luxembourg & 9.9 & 9.8 & 9.6 \\
Malta & 27.3 & 27.5 & 26.9 \\
Netherlands & 13.2 & 13.2 & 13.1 \\
Norway & 19.1 & 18.8 & 18.2 \\
Poland & 27.7 & 27.5 & 26.4 \\
Portugal & 22.8 & 22.9 & 23.2 \\
Romania & 34.1 & 32.8 & 30.9 \\
Slovak Republic & 18.9 & 18.3 & 17.2 \\
Slovenia & 27.0 & 26.4 & 25.3 \\
Spain & 22.7 & 22.4 & 17.3 \\
Sweden & 19.3 & 18.7 \\
United Kingdom & 12.7 & 12.3 \\
NMS average & 28.3 & 27.7 \\
Old Europe average & 18.2 & 18.0 & \\
\hline \hline & & & 2.3 \\
\hline
\end{tabular}

Source: Schneider et al. (2010a), own calculations 
Figure 1 - Change in the Shadow Economy in Europe between 1999-2001 and 20052007, Average Difference in Percentage Points

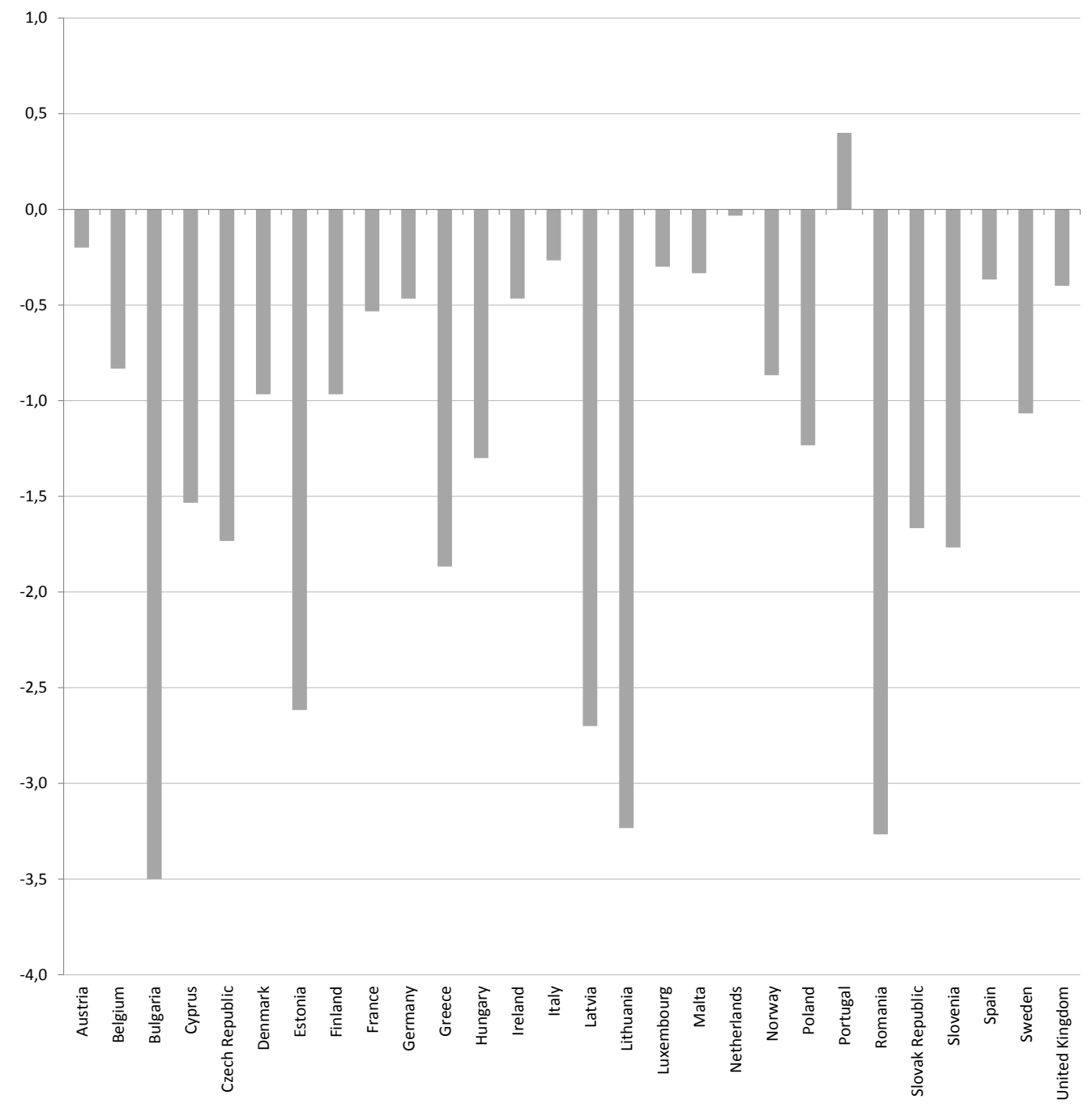

Source: Schneider et al. (2010a), own calculations 
General legitimacy of the state, trust in government and quality of governance and public services provided by the state are other crucial factors in determining the size of shadow economies. Enste (2003, p. 98) considers the shadow economy itself as "... an indicator of a serious deficit of legitimacy of the present social order and the existing rules of official economic activities". In turn, by increasing the benefits of contributing to the system, a high-quality governance and good public services might enhance individuals and business willness to operate formally, and outweigh the negative effects of large taxation and regulation (as was showed e.g., on case of Belgium - see Djankov et al., 2003).

Regulatory distortions and corruption represent another highly important factor influencing the size of the shadow economy (the effect was described in detail e.g., in Djankov et al., 2002, Johnson et al., 2000, or Friedman et al., 2000). Due to regulation, individuals and firms tend to be liable both to direct costs (fees, bribes etc.) and indirect costs (time, forgone profits etc.); moreover, what matters is both quantity and quality of regulation.

As regulation policy comes in "packages" of provisions with similar character, Loayza et al. (2005) classify the overall regulation relevant to the shadow economy into three categories: fiscal, labor and product-market regulations. Consequently, the authors assess the quality of the regulatory framework by a governance index, composed of indicators of corruption, prevalence of law and order, and the level of democratic accountability. They conclude that especially in product and labor markets a heavier regulatory burden suppresses economic growth and encourages informality. These adverse effects might be mitigated by a high quality governance.

Apparently, labor market regulations might have a considerable impact on inducing informality. Perry et al. (2007) show that the growth in shadow employment in Latin America and Caribbean was partially due to the increased burden of labor costs and other legal restrictions in several countries. Loayza (1994) came up with similar results on the adverse effect of labor regulations in Latin America. According to Perry et al. (2007), labor market institutions affect the shadow economy through three different channels. Firstly, excessive labor costs tend to reduce the number of jobs in the formal sector. Secondly, inappropriate legislation induces employees, self-employed and small firms to voluntarily opt for the informal sector. The last channel works through the rigidity of the labor market that impacts productivity growth.

Although the third channel may be potentially important within the European context, our research mainly focuses on the first and partly on the second channel. 12 In our analysis we investigate five main aspects of the labor market institutional framework: ${ }^{13}$ employment protection legislation,

\footnotetext{
12 See for instance the discussion on diverging economic performance of the United States and Europe in Nickell (1997).

13 See Nickell (1997), Riboud et al. (2001), Cazes and Nesporova, (2003).
} 
taxation of labor, minimum wage setting, collective bargaining over wages, and labor market policy spending.

\subsection{Employment Protection Legislation}

Employment protection legislation (EPL) is a part of overall regulations which define the legal conditions of hiring and firing. EPL mainly restricts the freedom in the formal sector, for instance limiting the employers' freedom to dismiss workers and, thus, it reduces the flows into, but also out of, unemployment. Restrictions on hiring and firing increase adjustment costs of the firms and might result into a preference for the use of fixed-term and temporary contracts. Strict employment protection might also reduce incentives to formal contracts by firms. Moreover, the increased costs can be shifted to employees, which in turn may be encouraged to turn informal. Generally, it is the enforcement rather than the extent of the regulation that is crucial.

As previously summarized, the adverse effect of rigid regulation on incentive for operating formally has been largely documented in the empirical literature. Johnson et al. (1997, 1998a, 1998b) and Loayza et al. (2005) present evidence of a significant positive effect of regulation on the shadow economy.

\subsection{Labor Taxation}

Taxes distort basic decision-making of individuals between work and leisure, affect the official labor supply and consequently also the shadow employment. The larger the tax wedge on labor, i.e. the difference between labor costs and take-home wage, the greater the incentive to avoid paying taxes and other contributions. According to Schneider and Enste (2000), increases in taxes and social contributions are one of the main determinants to the expansion of the shadow economy. ${ }^{14}$ The overall complexity of the tax system might play a role as well, as higher intricacy brings about both direct costs and opportunity costs to evade, and thus encourages hiding in the system (Schneider and Enste, 2000).

Johnson et al. (1998a, 1998b) argue that it is the extent of the regulatory and administrative discretion that is the main driving force to informality, not higher taxes per se. The authors demonstrate that higher income and corporate tax rates reduce the size of the shadow economy. Friedman et al. (2000) also identified a negative relationship between tax rates and the shadow economy and claimed that economic subjects escape into informality to reduce bureaucratic burden and corruption rather than to avoid taxes. Taxes, in their view, have two potentially offsetting effects: the direct ef-

${ }^{14}$ The adverse effect on increasing motives to turn informal might stem not only from taxation of labor (payroll taxes and social contributions), but also from indirect taxes (Spiro, 1993) and corporate tax burden (Johnson et al., 1998b). 
fect represents incentive to evade taxes, while the indirect effect encourages official economic activity through provision of a better legal environment.

\subsection{Minimum Wages}

Economic theorists have not reached a broad consensus regarding the consequences of the minimum wage so far. On the microeconomic level, it is generally accepted that the minimum wage might raise individual motivation and, therefore, increase productivity among low-paid workers (Stigler, 1946; Cahuc and Michell, 1996). Also, setting a minimum wage might shift the employment composition toward high-wage jobs (Acemoglu, 2001), and might work as a motivational device, within an efficiency wages framework (Rebitzer and Taylor, 1995; Manning, 1995) or in monopsony (Card and Krueger, 1995).

At the same time, it has been established that above a certain level, the negative effects of the minimum wage tend to prevail, as the effective minimum wage increases labor costs of the firms and prevents them from employing workers whose productivity does not exceed the minimum wage level (see e.g. Deere, Murphy, and Welch, 1995 or Neumark and Wascher, 2003). The higher the level of minimum wage, the larger the negative effects. The workers excluded from the formal employment therefore either enter the pool of unemployed or find a job in the informal sector, or become officially unemployed while working in the shadow economy ${ }^{15}$ For a summary of the empirical research on this issue see Brown et al. (1982) or OECD (1998).

\subsection{Trade Unions}

The role of trade unions in collective bargaining process is also a factor influencing wage setting, labor costs and flexibility of firms. Theory suggests that trade unions generally tend to raise wages, cause labor market rigidities and thus influence unemployment and formal employment. Their impact is directly proportionate to their coverage. Moreover, by promoting higher regulation of the formal labor market, trade unions might consequently indirectly promote higher informality. For a summary of the empirical findings see for instance $\operatorname{OECD}(1997,2004)$. However, trade unions might also provide a more intense control over informal activities of the companies. Using Bulgarian data, Zahariev (2003) showed that weak trade unions empower managements with opportunities to raise tax evasion and informal activities without employees' consent. The overall effect of trade unions on informality is therefore ambiguous.

${ }^{15}$ For details on higher prevalence of low-qualification and low-productivity labor in the informal sector see for instance Perry et al. (2007) for Latin America or Grabowski (2003) for Poland. 


\subsection{Labor Market Policies}

Labor market policies (LMP) may have an ambiguous impact on unemployment, labor market performance and incentives for informal behavior; however, to the authors' knowledge, this impact has never been clearly proved in the empirical literature on the determinants of informality. Nevertheless, according to our view, these policies influence informal labor markets through their effect on formal labor market flexibility and the motivation of individuals in searching for a job and in moderating their wage claims.

Active LMP aim at enhancing human capital and at sustaining the employability of the participants to the programs; these provisions may improve the efficiency of the job-matching process. Although negative effects might occur (e.g., substitution effects and deadweight losses as discussed in Martin, 2000), empirical studies often find a positive effect of these provisions on the employability of workers (OECD, 1993).

On the other hand, passive LMP may decrease the job-search intensity and the motivation of the unemployed to accept a job offer, may lower the economic costs of unemployment and, also, raise the employees' wage claims. In this way, such polices may enhance unemployment. Furthermore, passive LMP might strengthen the incentive for operating informally while simultaneously receiving unemployment benefits. At the same time, passive LMP might have a negative effect on informality, as securing income during unemployment might increase "informal reservation wage" of the unemployed and thus reduce the shadow economy. The generosity of unemployment insurance system is of particular importance (Layard et al., 1991). The overall effect is therefore again rather ambiguous.

\section{Data and Methodology}

This section describes the methodology and the data used in our analysis. To this end, we use various econometric models inspired by recent empirical research and by the economic theory set out in the previous parts of this paper. ${ }^{16}$ To estimate the effect of labor market institutions on the shadow economy, we use panel data estimation techniques and two-stage least squares estimation procedure with instrumental variables. Due to scarcity of the data, we use two data samples covering different countries and time periods. Definition and data sources for all the variables used in our analysis are presented in Annex 2.17

First, we constructed a panel sample of nineteen European countries

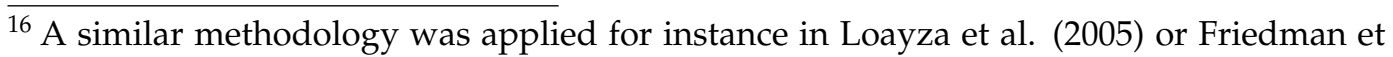
al. (2000).

${ }^{17}$ Descriptive statistics are available from the authors upon request. 
and used the data for the period 2000-2007 ("Basic sample") 18 The sample comprises fourteen old member states, Norway (which we classify as an old member state for the purposes of this paper), and four NMS. The source of the data is mainly the OECD and partly Eurostat, World Bank and Heritage Foundation. However, as this sample covers only four NMS (the Czech Republic, Slovakia, Hungary and Poland) we expand the analysis to some additional NMS in the second data sample ("Extended sample"). This panel consists of twenty-six countries, ten of which are the NMS, ${ }^{19}$ and covers years 2003 and 2007. The data sources are similar to those for the first sample. Furthermore, we extend OECD data by information from IZA database including all OECD measures of labor market institutions for the non-member states from Central and Eastern Europe. ${ }^{20}$ Yet, the lack of relevant data is a serious obstacle and the low number of observations (especially in the NMS sub-sample) might negatively affect the sensitivity of the results.

We examine the impact of institutional factors on a set of indicators for shadow production and employment. Emphasis is given to the shadow economy defined as percentage share in the official GDP (SHEC, Model "Shadow economy"). Further, we use the following proxies for the shadow employment: the share of labor force in unregulated self- and wage-employment, measured by the share of labor force not contributing to the pension system adjusted for the unemployment rate (CONTRIB, Model "Noncontributing to pension system"), the share of labor force employed in firms with fewer than ten employees (LESS10, Model "Small business employment"), the share of self-employed (SELFEMPL, Model "Self-employed") and the share of labor force employed without a legal written contract (CONTRACT, Model "Non-contract employment").21

Several techniques are employed to estimate the regression coefficients. The generalized two-stage least squares random-effects regression procedure is employed for panel data analysis performed for the Basic sample in models using Small business employment, Self-employed and Non-contract employment. Further, a two-stage least squares estimation procedure, applied to cross-sectional data, is used for the Extended sample in the model using Non-contributing to pension system as dependent variable, and a two-stage least squares estimation procedure applied to pooled panel data

\footnotetext{
${ }_{18}$ Austria, Belgium, Czech Republic, Denmark, Finland, France, Germany, Greece, Hungary, Ireland, Italy, Netherlands, Norway, Poland, Portugal, Slovakia, Spain, Sweden, and United Kingdom.

${ }^{19}$ Austria, Belgium, Bulgaria, Czech Republic, Denmark, Estonia, Finland, France, Germany, Greece, Hungary, Ireland, Italy, Latvia, Lithuania, Luxembourg, Netherlands, Norway, Poland, Portugal, Slovakia, Slovenia, Spain, Sweden, Romania, and United Kingdom.

${ }^{20}$ For details on the methodology see Lehmann and Muravyev (2009).

${ }^{21}$ For description of data sources and discussion of information relevancy of these indicators see Section 2 and Annex 2.
} 
is used on both samples in the model for the Shadow economy and the Extended sample in models using as dependent variables Small business employment, Self-employed and Non-contract employment, respectively. The feasibility of using these econometric approaches is tested by Durbin-WuHausman test ${ }^{22}$ and Breusch-Pagan Lagrange Multiplier test for the presence of random effects.

The regression equation has the following form for all samples:

$$
\begin{aligned}
X_{i t}= & \alpha+\beta_{1} E P L_{i t}+\beta_{2} M W_{i t}+\beta_{3} T U_{i t}+\beta_{4} T A X_{i t}+\beta_{5} L M P A_{i t}+ \\
& \beta_{6} L M P P_{i t}+\beta_{7} \ln G D P P C_{i t}+\beta_{8} F I S F_{i t}+\beta_{9} B U S F_{i t}+ \\
& \beta_{10} C O R R_{i t}+\beta_{11} R E G Q U A L_{i t}+\epsilon_{i t}
\end{aligned}
$$

where $X$ is SHEC, CONTRIB, SELFEMPL, LESS10, or CONTRACT depending on the regressions. For detailed description of all the models applied in our analyses see Annex 3.

We adopt OECD indicators (OECD, 2004, or Venn, 2009) on the strictness of employment protection. The OECD develops a set of indicators describing various aspects of EPL, which cover regular and temporary contracts and collective dismissals. The assigned scores are aggregated into a summary indicator using a set of weights. The resulting overall EPL index, version 2 (EPL2) covers conditions of regular and temporary contracts, and terms of collective dismissals. ${ }^{23}$ The index ranges from 0 to 6 . A low value of the index is indicative of more flexible legislation and liberal hiring and firing environment, while stricter protection is reflected in a higher value of the index. Data for old European countries and the Czech Republic, Poland, Slovakia and Hungary are available in a longer time series. Data for the remaining NMS come from IZA database and are available for 2003 and 2007 only.

Minimum wage $(M W)$ is a cluster variable constructed according to the level of the minimum wage, defined as a share of median wage in the economy for the Basic sample, and according to minimum wage level in purchasing power parities for the Extended sample.

The power of trade unions is approximated by the trade union density, defined as the percentage of workers inscribed to trade unions $(T U)$.

${ }^{22}$ Durbin-Wu-Hausman test was replaced by xtoverid test procedure in Stata application, introduced by Schaffer and Stillman (2006) for testing coefficients estimated in the RE and FE panel estimation procedure in case that covariance matrix in Hausman test was not positive definite.

${ }^{23}$ We use the overall measure of employment protection that covers both regular and temporary contracts. Yet, several studies show that the impact of EPL on economic performance may differ between these two types of workers (see e.g. Griffith and Macartney, 2014, or Bassanini et al., 2009). We tested for this difference by estimating separate regressions with EPL for regular contracts and with EPL for temporary contracts including regulation of fixed-term and temporary work agency contracts. The results point to a significant positive impact of both variables, although the effect of EPL for temporary contracts is slightly weaker. These results are not reported in this paper and can be provided from the authors upon request 
The role of the tax system is investigated using the indicator developed by OECD on total tax wedge on labor. It reflects the average personal income tax and social security contribution rates, expressed as a percentage of gross labor income $(T A X)$. Such data come from the same sources used for the EPL indicator.

Finally, to identify the influence of labor market policies, we include expenditure on active (LMPA) and passive labor market policies (LMPP), expressed as percentages share of GDP per percentage point of unemployment. Because of possible simultaneity bias, both variables on labor market policies expenditure are instrumented with the average value of the unemployment rate in the preceding five years. ${ }^{24}$

Economic theory and empirical research described in previous sections indicate the expected effect of the variables used in our regressions. Policies that distort the effective functioning of the labor markets, such as high minimum wages and excessive employment protection legislation, are bound to increase attractiveness of the shadow economy. Nevertheless, there is no consensus on the impact of trade unions, labor taxes and income support during unemployment.

In addition, we control for the effect of other political-economic factors. First, we control for the level of a country's economic development by adding the variable GDP per capita, expressed in purchasing power parities $(G D P P C)$. In line with previous research in the field, the variable is taken in logs. However, this variable is omitted in the model which uses the share of the shadow economy in official GDP as a dependent variable, because GDP per capita was also utilized by Schneider et al. (2010a) as a causal variable in the structural equation of the MIMIC estimation model of the shadow economy. Instead, we use life expectancy at birth (LEXP) as a proxy for the level of socio-economic development as it shows a strong positive correlation with GDP per capita in European countries ${ }^{25}$

Furthermore, two additional indicators for the degree of market regulation are considered: fiscal and business freedom. The index of fiscal freedom has an inverse relationship to the overall tax burden imposed by the government (FISF) ${ }^{26}$ Business freedom is a quantitative measure of the ability to do business and is inversely related to the overall burden of regulation, as well as to the efficiency of government in the regulatory process (BUSF) ${ }^{27}$

${ }^{24}$ These variables might be endogenous because they relate the expenditure to the actual rate of unemployment, potentially affecting the decision about turning informal.

${ }^{25}$ The correlation coefficient equals to 0.6944 and it is significant at $1 \%$ level for twentyeight European countries in 2000-2007.

${ }^{26}$ Fiscal freedom is a composite indicator which refers to overall tax burden imposed by government. It is composed of three factors: top tax rate on individual income, top tax rate on corporate income, and total tax revenue as a percentage of GDP. This indicator should guarantee existence of no collinearity between this variable and variable $T A X$ which is defined as average personal income tax as a percentage of labor costs.

${ }^{27}$ Both control variables have also been utilized by Schneider et al. (2010a) as explana- 
Finally, informality might also be affected by political factors. To account for such issues, we include a proxy for the control of corruption in the country and an index of regulatory quality (CORR, REGQUAL) ${ }^{28}$

As the Basic sample covers only four of all NMS, it is impossible to conduct a separate analysis for this group of countries. Instead, we are only able to examine the different roles of institutions in all countries, compare them to the roles of institutions in the old member states and draft conclusions for the NMS, using a modified Chow test (see also Cazes and Nesporova, 2003). ${ }^{29}$ A similar test was also applied to the Extended sample covering more NMS and thus allowing for separate regressions; nevertheless, the sample still suffers from rather low reliability given by lack of relevant data. Given the above mentioned limitations, differences between the NMS and the old member states can be studied only partially.

The direction of causality which we assume could be in some cases subject to criticism, given the close mutual interaction between the development of the shadow economy and labor market institutions. Moreover, labor market institutions might even be endogenous and their effect might vary over time ${ }^{30}$ Our model is also unable to explain individual motives and flows of economic subjects between formality and informality. Consequently, our results should be interpreted with caution and all these limitations should be born in mind.

tory variables in several specifications of the MIMIC model. However, as follows from Schneider et al. (2010b), comparable data for the 162 countries that are used in our analysis were obtained from one particular specification that excludes these two variables. As causal variables, this specification only covers the size of the government, the unemployment rate, GDP per capita, and government effectiveness. Consequently, including fiscal and business freedom in our estimations should not bias the results.

28 Some authors (e.g., Lehmann and Muravyev, 2009) include the macro environment and policy variables in a lagged form. The underlying logic is that it is reasonable to expect the outcome of interest in time $t$ to be more related to the hypothesized causal variable in time $t-1$. In our estimations, we assume that the environment prevailing at the time the decision is being made has the major effect on decision-making of economic subjects and, therefore, we do not use lagged form of these control variables. Furthermore, there exists substantial inertia in development of macroeconomic and policy environments, which reduces potential differences in outcomes of these two approaches. Nevertheless, we considered this eventuality as well and we checked robustness of our results by utilization of models with lagged macro environment and policy variables. The results were not altered significantly by this step.

${ }^{29}$ We used a modified version of the test hypotheses and statistics, because number of observations in the NMS group is smaller than the number of parameters, $n_{N M S}$ and thus we cannot use the standard methods in this case. We test the hypothesis $H_{0}$ : $E\left(y \mid X ; \beta_{O E}\right)=E\left(y \mid X ; \beta_{N M S}\right)$. This is done by calculating the statistic

$$
F=\frac{\frac{S S R_{T}-S S R_{O E}}{n_{N M S}}}{\frac{S S R_{O E}}{n_{O E}-k}} \simeq F\left(n_{N M S}, n_{O E-k}\right)
$$

${ }^{30}$ For a detailed discussion on this topic see e.g., Freeman (2007). 


\section{Results of Empirical Estimations}

In this section, we present estimates for the effect of labor market institutions on various indicators of shadow production and employment. Theory suggests that dependent variables in models Shadow economy, Noncontributing to pension system and Non-contract employment should be strongly correlated, as they have a tighter relationship to informality. In contrast, dependent variables of models Small business employment and Self-employed mainly reflect different phenomena and their relationship to the examined variable, i.e. the shadow employment, is expected to be weaker.

\subsection{Main Estimates: Share of the Shadow Economy in GDP}

Table 2 shows the results obtained using the share of the shadow economy in official GDP as a dependent variable. The explanation power of the models, as measured by R-squared varies from $68 \%$ for total sample of the Basic model (col. 1) to more than $84 \%$ for the Extended sample (cols. 4-5).

The main result of our regression analysis is the unambiguous confirmation of the strong positive effect of stricter employment protection legislation on the shadow production. This effect is significant and robust across specifications, confirming our hypotheses based on previous theoretical and empirical research in this area. Raising the strictness of employment protection legislation by one point (out of six) increases the shadow production by approximately 3\% of GDP. Results on the Basic sample also suggest that the share of shadow production increases by 0.1 percent point each one-percent increase in trade union density. Yet, this result is not confirmed for the NMS in the Extended sample as pointing to a negative relationship between the share of the shadow economy and the trade union density for this group of countries.

The estimates of the effect of labor taxation, minimum wage, active and passive labor market policy expenditure are inconclusive. The negative effect of taxation arising from the Extended sample (cols. 3-4) is not confirmed in the Basic model (cols. 1-2). This may reflect the possibility that a higher fiscal burden might be associated with the provision of high-quality public services or with a better legal environment. Yet, the result suffers from limited robustness. Furthermore, passive labor market policy expenditure exhibits a negative effect on shadow production in Basic sample (significant at $10 \%$ only in col. 1). A similar, highly significant effect can be found for the "old European" countries in the Basic sample and for the NMS in the Extended sample. Furthermore, the positive effect of active labor market policy expenditures found for the "old European" countries in Basic model is consistent with the result of the NMS in the Extended model. The counterintuitive effect might be explained by a possible abuse of the active LMP 
Table 2 - Results of Model Shadow economy (SHEC)

\begin{tabular}{|c|c|c|c|c|c|}
\hline & \multicolumn{2}{|c|}{ Basic sample } & \multicolumn{3}{|c|}{ Extended sample } \\
\hline & Total & Old Europe & Total & Old Europe & NMS \\
\hline & (1) & (2) & (3) & (4) & (5) \\
\hline Employment protection legislation & $3.1417 * * *$ & $3.8406 * * *$ & $4.1253 * * *$ & $2.3097 * * *$ & $7.2679 * * *$ \\
\hline Minimum wage & 0.3807 & -0.2759 & -0.5421 & -0.1571 & -1.1387 \\
\hline Trade union membership & $0.1133^{* * *}$ & $0.1180^{* * *}$ & 0.0534 & $0.1321 * * *$ & $-0.3987 * * *$ \\
\hline Total tax wedge on labor & 0.0175 & 0.0200 & $-0.2085^{* * *}$ & $-0.1464 *$ & 0.1177 \\
\hline Active LMP expenditure expenditure & 12.4536 & $16.2840 * *$ & -8.3348 & -9.5048 & $86.9242^{* * *}$ \\
\hline Passive LMP expenditure & $-7.8156 *$ & $-10.7680 * * *$ & -3.8171 & 3.6591 & $-251.5570 * * *$ \\
\hline Life expectancy & -0.0751 & $-0.4543 * *$ & $-0.8539 * * *$ & -0.4574 & -0.5207 \\
\hline Fiscal freedom & 0.0252 & $0.0576 *$ & $-0.1576 * *$ & -0.0536 & -0.1013 \\
\hline Business freedom & 0.0163 & 0.0254 & $0.1253^{* *}$ & 0.0390 & 0.1540 \\
\hline Control of corruption & $-4.8677^{* * *}$ & $-8.1540 \quad * * *$ & $-6.4039 * * *$ & $-6.3975 * * *$ & $13.2963 * * *$ \\
\hline Regulatory quality & -1.4813 & $2.9438 *$ & 1.0627 & -3.5333 & $-25.3501 * * *$ \\
\hline constant & 19.0105 & 44.9800 & $92.8741 * * *$ & $66.3346 * *$ & $76.1272 * *$ \\
\hline R sq. & 0.6759 & 0.8553 & 0.7972 & 0.8458 & 0.8419 \\
\hline $\mathrm{N} /$ groups & 152 & 120 & 49 & 31 & 18 \\
\hline Method & POOL IV 2SLS & POOL IV 2SLS & POOL IV 2SLS & POOL IV 2SLS & POOL IV 2SLS \\
\hline \multicolumn{6}{|l|}{ Tests $p$-values } \\
\hline Wald test $\mathrm{Chi}^{2}$ & 0.0000 & 0.0000 & 0.0000 & 0.0000 & 0.0000 \\
\hline Durbin-Wu-Hausman $\mathrm{Chi}^{2}$ & 0.9935 & & 0.0063 & & \\
\hline Xtoverid Sargan-Hansen $\mathrm{Chi}^{2}$ & 0.0459 & & 0.0002 & & \\
\hline Breusch-Pagan LM Chi ${ }^{2}$ & 0.0000 & & 0.0001 & & \\
\hline Chow test: all coefficients / EPL only & 0.2619 & .0053 & & $0.3213 / 0.0385$ & \\
\hline
\end{tabular}

Note: ${ }^{* * *}$ significant at $1 \%$ level, ${ }^{* *}$ significant at $5 \%$ level, ${ }^{*}$ significant at $10 \%$ level. POOL IV 2SLS - pooled twostage least squares procedure with instrumental variables on panel data; robust standard errors utilized. NPD covariance matrix in the test not positive definite. The detailed description of all the models applied in our analyses is given in Annex 3.

Source: Schneider et al. (2010a), OECD, Eurostat, World Bank, Heritage Foundation, IZA, own calculations.

programs where, due to the low efficiency of state control over these policy measures, the participants to the programs may be able to both work informally and be subscribed to the programs. Further, the negative effect of passive LMP might be driven by the fact that securing social income increases informal reservation wage of the unemployed and reduce the shadow economy. Finally, in our estimations the effect of the minimum wage on shadow production is insignificant for both samples.

The control of corruption is significant and seems to differ between the old and the new member states. While this variable seems to boost the share of shadow production in the group of NMS, it has an opposite (and rather intuitive) effect in the old member states (that dominate overall results in both samples). The counterintuitive result for the former group of countries might be determined by the generally high level of corruption in the public administration of the new EU member states, pushing private entrepreneurs out of the official economy. The fact that corruption is so deeply rooted in these countries results in an inertia which hinders functioning of 
the traditional mechanisms prevailing in the old European group ${ }^{31}$

Business freedom appears to increase the shadow production, albeit it should be acknowledged that this finding suffers from limited robustness, as it is significant only in first regression for the Extended sample. Similarly, the result for fiscal freedom is inconclusive, as this variables has a positive effect on the shadow production in old European countries in the Basic sample (significant at $10 \%$ only), but denotes a negative effect in the Extended sample. Regulatory quality seems to have an insignificant effect on the shadow production.

Taking into account the potentially different developments in the NMS countries before 2004 (i.e. the year of accession of ten of the NMS to the EU) do not alter our results substantially. To examine the potential differences in the role of the explanatory variables between the total sample and the old European countries we apply modified Chow tests, as described above. The results of the tests do not reject the hypothesis of the stability of coefficients between these two groups for both estimates at a 5\% significance level. However, we also test for the difference in the effect of the only labor market institutional variable that proves to have an unambiguous and robust impact on the dependent variable in our estimations, i.e. employment protection legislation. Our results reject the hypothesis of equality of the EPL coefficient between country groupings both in the Basic and the Extended sample. This would indicate that employment protection legislation affects the expansion of the shadow economy in a different extent in the old European countries and in the NMS.

\subsection{Robustness Checks: Shadow Employment Indicators}

\subsubsection{Share of Labor Force Non-contributing to Pension System}

Table 3 summarizes estimates of the model yielded using the share of labor force not contributing to the pension system as a dependent variable. Because of data constraints this analysis is limited to the Extended sample only. The fit of the model is quite strong (R-squared is $86 \%$ ). Indeed, all explanatory variables, except for the minimum wage, trade union density and business freedom, exhibit a significant impact on the dependent variable. Labor taxation and fiscal freedom both have a negative impact on this proxy for the shadow employment. Labor taxation might negatively influence shadow employment by providing funds to improve the quality of public services and the provision of a better legal environment. Further-

\footnotetext{
${ }^{31}$ Dreher and Schneider (2010) analyze the different nature of the relationship between corruption and informality in high- and low-income countries. According to these authors, in high-income countries, people use corruption to engage in more activities in the official economy. This hypothesis, which is not confirmed by the results of these authors, appears consistent with the pattern revealed by our group of NMS.
} 
Table 3 - Results of Model Non-contributing to pension system (CONTRIB)

\begin{tabular}{|l|r|}
\hline \multirow{2}{*}{} & Extended sample \\
\cline { 2 - 2 } & Total \\
\hline Employment protection legislation & $9.4872^{* *}$ \\
\hline Minimum wage & $0.0106^{*}$ \\
\hline Trade union membership & $0.2190^{*}$ \\
\hline Total tax wedge on labor & $-0.3733^{* *}$ \\
\hline Active LMP expenditure expenditure & $-138.9402^{* * *}$ \\
\hline Passive LMP expenditure & $63.5549^{* * *}$ \\
\hline Log GDP per capita & $16.0823^{* * *}$ \\
\hline Fiscal freedom & $-0.1456^{* * *}$ \\
\hline Business freedom & $0.0196^{* *}$ \\
\hline Control of corruption & $-21.1944^{* * *}$ \\
\hline Regulatory quality & $25.5393^{* * *}$ \\
\hline Constant & $-54.3431^{* *}$ \\
\hline & \\
\hline R sq. & $0.8601^{*}$ \\
\hline N & $17^{*}$ \\
\hline Method & IV 2SLS \\
\hline Wald test Chi ${ }^{2}$ statistics $p$-value & $0.0000^{*}$ \\
\hline
\end{tabular}

Note: ${ }^{* * *}$ significant at $1 \%$ level, ${ }^{* *}$ significant at $5 \%$ level, ${ }^{*}$ significant at $10 \%$ level. IV 2 SLS - two-stage least squares procedure with instrumental variables on cross-sectional sample; robust standard errors utilized. The detailed description of all the models applied in our analyses is given in Annex 3.

Source: OECD, Eurostat, World Bank, Heritage Foundation, IZA, own calculations.

more, a negative effect is also detected for active labor market policy and corruption control, in line with our expectations.

On the other hand, employment protection legislation, together with passive labor market policy expenditure, GDP per capita, and regulatory quality are associated with higher levels of shadow employment. The result for EPL confirms our previous evidence. The positive coefficient for passive labor market policies may be explained by a possibility to abuse the system by receiving unemployment benefits, while simultaneously engaging in informal activities. ${ }^{32}$ The positive relationship between the level of economic development and the share of non-contributing workers seems to contradict the results of the previous section, as well as earlier research. This counterintuitive finding might be explained with the increasingly generous pension benefits; these are unrelated to life-time contributions, mak-

\footnotetext{
32 To the authors' knowledge, the impact of passive labor market policies has never been clearly proved in the literature on the determinants of informality. Several studies find a positive correlation between level and duration of unemployment benefits and the length of the unemployment status (see e.g. Margolis et al., 2012). At the same time, the unemployed might be prone to be engaged in informal activities.
} 
ing thus contributing to the pension systems redundant in richer European countries, as the non-contributing periods are only partially reflected in the pension scheme. Yet, this result must be regarded with caution and be subjected to further research. As far as this explanatory variable is concerned, we also examined the possibility that our results might be biased due to adjustment of the dependent variable for the unemployment rate. This might happen for instance if people work informally and declare themselves as unemployed in order to receive benefits, as it is indicated by the coefficient for passive labor market policies. However, the analysis using unadjusted data yields results similar to those presented in Table 3.33

\subsubsection{Employees in Small Firms and Self-employed}

In this section, we estimate the effect of labor market institutions on the share of workers in small firms with less than ten employees and on the share of self-employed. Both measures should reflect the labor market restrictions that presumably prevent firms from expanding beyond a certain size, approximated here by the number of employees, or push workers into self-employment. These results are shown in Tables 4 and 5, respectively.

The explanatory capacity of our empirical models lessens using these two proxies for the shadow employment. This holds in particular for selfemployed. This is probably caused by a substantially more complex relationship between the labor market indicators and our dependent variables. The results for the model using the share of employment of small business enterprises are not very statistically robust and are not consistent with our previous sets of estimates (see Table 2 and 3) as well as with the results we get using the share of Non-contract employees (see below).

As Table 4 shows, the strictness of employment protection legislation is confirmed to have a positive effect on the shadow economy: each one-point increase in EPL strictness raises the share of employment in small firms by almost $10 \%$. Labor taxation reduces the share of small-firm workers in total labor force, confirming the negative relationship found in the previous section 34

Both in Basic and the Extended sample, the effect of passive labor market policies is ambiguous; conversely, business freedom tends to increase employment in small firms. In the Basic sample, the effects of other variables - trade union density, active labor market policy expenditures, minimum wage, economic development, fiscal freedom, control of corruption,

\footnotetext{
${ }^{33}$ The results obtained using the share of labor force not contributing to the pension system not adjusted for the unemployment rate as dependent variable are available from the authors upon request.

${ }^{34}$ We examined this relationship further using a finer threshold for firm size, i.e. considering the share of labor force employed in firms with fewer than five employees. The data come from EU-SILC and spans from 2005 to 2007. These results confirm the negative relationship between employment in small firms and labor taxation.
} 
Table 4 - Results of Model Small business employment (LESS10)

\begin{tabular}{|c|c|c|c|c|c|}
\hline & \multicolumn{2}{|c|}{ Basic sample } & \multicolumn{3}{|c|}{ Extended sample } \\
\hline & Total & Old Europe & Total & Old Europe & NMS \\
\hline & (1) & (2) & (3) & (4) & (5) \\
\hline Employment protection legislation & $9.5992 * * *$ & $11.6807 * * *$ & $6.1988 * * *$ & $16.9680 *$ & $-5.3567 * * *$ \\
\hline Minimum wage & -1.0595 & -2.0185 & $-3.1874 * *$ & $-4.0462 * *$ & $-5.7700 * *$ \\
\hline Trade union membership & -0.0164 & 0.0450 & -0.0516 & 0.1096 & $0.5342 * * *$ \\
\hline Total tax wedge on labor & -0.2569 & $-0.4995 * *$ & $-0.7366 * *$ & $-2.1621 *$ & -0.1829 \\
\hline Active LMP expenditure & 43.2387 & -0.3349 & -54.5490 & $-388.9695^{*}$ & $-79.3016 * * *$ \\
\hline Passive LMP expenditure & $-43.4472 * *$ & -20.1008 & -2.2491 & $133.0819 *$ & $455.4081 * * *$ \\
\hline Log GDP per capita & 6.9031 & 13.9637 & $19.0370 * *$ & 59.6104 & -2.5173 \\
\hline Fiscal freedom & -0.0524 & -0.1028 & $-0.2703 *$ & -1.1172 & $0.2014 * *$ \\
\hline Business freedom & $0.3234 * * *$ & $0.3345^{* * *}$ & 0.2060 & 0.6140 & $-0.1992 *$ \\
\hline Control of corruption & -5.9810 & $-8.3002 *$ & -4.9543 & -9.8134 & $-9.3639 *$ \\
\hline Regulatory quality & 4.5365 & 2.3194 & -8.3761 & -11.8015 & $28.4193 * * *$ \\
\hline Constant & -20.0245 & -31.3592 & 12.6085 & -63.2875 & 8.6908 \\
\hline R sq. Within/Between & $0.1336 / 0.5686$ & $0.1257 / 0.7480$ & & & \\
\hline R sq. & 0.3464 & 0.4208 & 0.3497 & 0.3454 & 0.7602 \\
\hline $\mathrm{N} /$ groups & $143 / 19$ & $112 / 15$ & 48 & 30 & 18 \\
\hline Method & RE & RE & POOL IV 2SLS & POOL IV 2SLS & POOL IV 2SLS \\
\hline \multicolumn{6}{|l|}{ Tests $p$-values } \\
\hline Wald test $\mathrm{Chi}^{2}$ & 0.0018 & 0.0001 & 0.0009 & 0.0042 & 0.0000 \\
\hline Durbin-Wu-Hausman $\mathrm{Chi}^{2}$ & \multicolumn{2}{|l|}{0.1369} & \multicolumn{3}{|l|}{0.9677} \\
\hline Xtoverid Sargan-Hansen $\mathrm{Chi}^{2}$ & \multicolumn{2}{|l|}{0.1628} & \multicolumn{3}{|l|}{ NA } \\
\hline Breusch-Pagan LM Chi ${ }^{2}$ & \multicolumn{2}{|l|}{0.0040} & \multicolumn{3}{|l|}{0.0782} \\
\hline Chow test: all coefficients / EPL only & \multicolumn{2}{|c|}{0.9479 / 0.4231} & \multicolumn{3}{|c|}{$0.9985 / 0.0399$} \\
\hline
\end{tabular}

Note: ${ }^{* * *}$ significant at $1 \%$ level, ${ }^{* *}$ significant at $5 \%$ level, ${ }^{*}$ significant at $10 \%$ level. RE - random effects generalized least squares estimation method, POOL IV 2SLS - pooled two-stage least squares procedure with instrumental variables on panel data; robust standard errors utilized. NA - model fitted on these data fails to meet the assumptions of the test. The detailed description of all the models applied in our analyses is given in Annex 3 .

Source: OECD, Eurostat, World Bank, Heritage Foundation, IZA, own calculations.

and regulatory quality - are statistically insignificant. In the Extended sample, active labor market policies are found to exert a negative effect on employment in small firms in the new member states, but not in the old EU member states. Furthermore, the minimum wage exhibits a negative effect on the dependent variable in the Extended sample which, reasonably, might reflect a purely legal employment in small companies, but it fails to meet our hypotheses regarding the effect on shadow employment, similarly to the results of previous models.

The results for the model relating our set of explanatory variables to the share of self-employed are not very informative as the effect of regressors changes remarkably with the sample of countries considered.

Using the modified Chow tests, we were not able to reject the hypothesis of stability of the overall set of coefficients between NMS and old European countries in both sets of regressions in Table 4 (small business employment), and in the Extended model of Table 5 (self-employed). In contrast, results for the model using self-employed indicate a different impact of the explanatory variables between the old European countries and the NMS in 
Table 5 - Results of Model Self-employed (SELFEMPL)

\begin{tabular}{|c|c|c|c|c|c|}
\hline & \multicolumn{2}{|c|}{ Basic sample } & \multicolumn{3}{|c|}{ Extended sample } \\
\hline & Total & Old Europe & Total & Old Europe & NMS \\
\hline & $(1)$ & $(2)$ & (3) & (4) & (5) \\
\hline Employment protection legislation & -0.5499 & $0.9708^{*}$ & $2.1267^{*}$ & $1.7783^{* *}$ & 2.0232 \\
\hline Minimum wage & -0.0558 & 0.2647 & 0.0258 & -0.1448 & 1.2082 \\
\hline Trade union membership & $-0.0967 * *$ & -0.0381 & $0.0723 *$ & $0.0722 * *$ & -0.1344 \\
\hline Total tax wedge on labor & 0.0083 & -0.0633 & $-0.3400 * * *$ & $-0.1236 *$ & 0.2239 \\
\hline Active LMP expenditure & 2.0591 & 4.5337 & $-81.4802 * * *$ & -10.0164 & -37.7993 \\
\hline Passive LMP expenditure & -1.9254 & $-6.9724 * *$ & $35.6506 * * *$ & 5.0697 & 15.1356 \\
\hline Log GDP per capita & $-3.6395 * * *$ & $-8.6731 * * *$ & $4.9850 * *$ & $-8.5828 * * *$ & 1.4612 \\
\hline Fiscal freedom & $0.0545^{* * *}$ & 0.0372 & $-0.1727 * * *$ & $0.1274 * *$ & 0.0156 \\
\hline Business freedom & 0.0024 & $0.0275 * *$ & 0.0160 & -0.0262 & -0.0744 \\
\hline Control of corruption & 0.6946 & $-2.9335 * * *$ & $-6.6594 * * *$ & $-9.5263 * * *$ & -2.2346 \\
\hline Regulatory quality & 0.9451 & 0.6155 & $-0.6917 * * *$ & $7.8841 * *$ & -8.8696 \\
\hline Constant & $24.6757^{* * *}$ & $45.8326^{* * *}$ & $23.8789^{* * *}$ & $41.8845^{* * *}$ & 9.1444 \\
\hline R sq. Within / Between & $0.2055 / 0.0666$ & $0.0881 / 0.7635$ & & & \\
\hline R sq. & 0.0761 & 0.7565 & 0.5790 & 0.9009 & 0.7119 \\
\hline $\mathrm{N} /$ Gross & $149 / 19$ & $118 / 15$ & 49 & 31 & 18 \\
\hline Method & RE & RE & POOL IV 2SLS & POOL IV 2SLS & POOL IV 2SLS \\
\hline \multicolumn{6}{|l|}{ Tests $p$-values } \\
\hline Wald test $\mathrm{Chi}^{2}$ & 0.0022 & 0.0000 & 0.0000 & 0.0000 & 0.0000 \\
\hline Durbin-Wu-Hausman $\mathrm{Chi}^{2}$ & \multicolumn{2}{|l|}{0.0000} & \multicolumn{3}{|l|}{$0.0000 \mathrm{NPD}$} \\
\hline Xtoverid Sargan-Hansen $\mathrm{Chi}^{2}$ & \multicolumn{2}{|l|}{0.0751} & \multicolumn{3}{|l|}{0.0065} \\
\hline Breusch-Pagan LM Chi ${ }^{2}$ & \multicolumn{2}{|l|}{0.0000} & \multicolumn{3}{|l|}{0.0066} \\
\hline Chow test: all coefficients / EPL only & \multicolumn{2}{|c|}{$0.0000 / 0.0632$} & \multicolumn{3}{|c|}{$0.9534 / 0.6071$} \\
\hline
\end{tabular}

Note: ${ }^{* * *}$ significant at $1 \%$ level, ${ }^{* *}$ significant at $5 \%$ level, ${ }^{*}$ significant at $10 \%$ level. RE - random effects generalized least squares estimation method, POOL IV 2SLS - pooled two-stage least squares procedure with instrumental variables on panel data; robust standard errors utilized. NPD - covariance matrix in the test not positive definite. The detailed description of all the models applied in our analyses is given in Annex 3 .

Source: OECD, Eurostat, World Bank, Heritage Foundation, IZA, own calculations.

the Basic model, both for overall set of coefficients and for the EPL coefficient only (significant at $10 \%$ level).

\subsubsection{Share of Workers without a Legal Written Contract}

The last model examined considers the share of labor force employed without a legal written contract as a dependent variable. The results are summarized in Table 6 and are close to those of Table 2 and 3, based on the indicators of the shadow production and on the share of workers noncontributing to pension system. The good predictive capacity of the model remains confirmed, apart from the regressions in the Basic model, where Rsquare is less than 0.11 and the Wald test p-value on the significance of all regressors is 0.18 for the old European countries. For this reason, we omit these results from further analysis and discuss cols. (3)-(5) of Table 6, only.

In line with our earlier estimates, EPL is found with a significant and positive effect, indicating that the excessive legal protection leads to a higher share of workers without a written contract. The other explanatory variables show weaker effects. As expected, a higher trade union density is associated with a lower share of workers without formal contracts, as trade unions may exercise pressure on government to impose harsher penalties for non-contract workers. The level of labor taxation is found to reduce the shadow economy, but this effect is significant only for total sample of coun- 
Table 6 - Results of Model Non-contract employment (CONTRACT)

\begin{tabular}{|c|c|c|c|c|c|}
\hline & \multicolumn{2}{|c|}{ Basic sample } & \multicolumn{3}{|c|}{ Extended sample } \\
\hline & Total & Old Europe & Total & Old Europe & NMS \\
\hline & $(1)$ & $(2)$ & (3) & $(4)$ & $(5)$ \\
\hline Employment protection legislation & $4.1585^{* * *}$ & 0.0980 & $2.7880 * *$ & $6.5737^{* * *}$ & $6.9879 * * *$ \\
\hline Minimum wage & $-0.5562 *$ & -0.2438 & -0.0925 & -0.4403 & $6.2950 * *$ \\
\hline Trade union membership & $-0.1036^{*}$ & -0.0752 & $-0.1006 *$ & $-0.0865 * *$ & $-0.5563 * * *$ \\
\hline Total tax wedge on labor & $0.1701 *$ & 0.0614 & $-0.1898 * *$ & -0.2152 & -0.2119 \\
\hline Active LMP expenditure & 5.5891 & -6.2919 & -20.5066 & -15.8073 & 44.6655 \\
\hline Passive LMP expenditure & -1.3019 & 4.9171 & -1.8657 & -0.3121 & -160.8801 \\
\hline Log GDP per capita & $4.7619 * *$ & -3.0364 & -1.5095 & -8.8021 & 0.9432 \\
\hline Fiscal freedom & 0.0340 & -0.0020 & $-0.2135 * * *$ & -0.1099 & $-0.4078 * *$ \\
\hline Business freedom & -0.0075 & $0.0354^{* *}$ & -0.0381 & $0.1100 *$ & $-0.2582 *$ \\
\hline Control of corruption & $-2.9826 * * *$ & -0.6461 & $5.4242 * *$ & $4.0122 *$ & 3.7078 \\
\hline Regulatory quality & 1.9812 & 0.0067 & -4.1791 & 2.2713 & -11.2454 \\
\hline constant & $-17.8050^{* *}$ & 19.8145 & $35.6348^{* * *}$ & $27.7419^{* * *}$ & $61.5898^{* * *}$ \\
\hline R sq. Within / Between & $0.3339 / 0.1076$ & $0.1382 / 0.0676$ & & & \\
\hline R sq. & 0.1058 & 0.0612 & 0.4100 & 0.5604 & 0.7847 \\
\hline $\mathrm{N} /$ groups & $146 / 19$ & $115 / 15$ & 49 & 31 & 18 \\
\hline Method & $\mathrm{RE}$ & RE & POOL IV 2SLS & POOL IV 2SLS & POOL IV 2SLS \\
\hline \multicolumn{6}{|l|}{ Tests $p$-values } \\
\hline Wald test $\mathrm{Chi}^{2}$ & 0.0000 & 0.1843 & 0.0000 & 0.0000 & 0.0000 \\
\hline Durbin-Wu-Hausman Chi ${ }^{2}$ & \multicolumn{2}{|l|}{ NA } & \multicolumn{3}{|l|}{$0.2015 \mathrm{NPD}$} \\
\hline Xtoverid Sargan-Hansen $\mathrm{Chi}^{2}$ & \multicolumn{2}{|l|}{0.0740} & \multicolumn{3}{|l|}{0.2707} \\
\hline Breusch-Pagan LM Chi ${ }^{2}$ & \multicolumn{2}{|c|}{0.0000} & \multicolumn{3}{|l|}{0.0005} \\
\hline Chow test: all coefficients / EPL only & \multicolumn{2}{|c|}{$0.1582 / 0.1711$} & \multicolumn{3}{|c|}{$0.9994 / 0.9859$} \\
\hline
\end{tabular}

Note: ${ }^{* * *}$ significant at $1 \%$ level, ${ }^{* *}$ significant at $5 \%$ level, ${ }^{*}$ significant at $10 \%$ level. RE - random effects generalized least squares estimation method, POOL IV 2SLS - pooled two-stage least squares procedure with instrumental variables on panel data; robust standard errors utilized. NPD - covariance matrix in the test not positive definite.NA - model fitted on these data fails to meet the assumptions of the test. The detailed description of all the models applied in our analyses is given in Annex 3.

Source: OECD, Eurostat, World Bank, Heritage Foundation, IZA, own calculations.

tries (col. 3). On the other hand, a higher minimum wage seems to increase the share of workers without a contract, but only in the group of the new EU members. Instead, both active and passive labor market policy do not have a significant effect on our proxy for non-contract employment.

Of all of the other control variables, only fiscal freedom and control of corruption seem to have a significant effect. The control of corruption tends to boost non-contract employment in total Extended sample, but the effect was not confirmed on its sub-samples. On the contrary, a greater fiscal freedom is associated with a lower non-contract employment. The level of economic development, as measured by GDP per capita, business freedom and the regulatory quality all show statistically weak effects.

The results of Chow tests do not allow to reject the hypothesis of stability of coefficients between these two groups of countries in either samples, both for the whole set of coefficients and for the EPL coefficient only.

\section{Discussions and Conclusions}

This paper has studied the role of labor market institutions in the development of the shadow economy in Europe. We have adopted several estimation approaches on different data samples and control for an array of confounding institutional factors. Estimates were obtained using different 
proxies for the shadow economy. The most robust findings come from the specifications using the shadow production as a percentage share of official GDP, the share of labor force not contributing to the pension system and the share of labor force employed without a legal written contract.

We have shown that stricter legislation brings about a larger shadow sector. This impact somewhat differs between older and newer member states of the European Union. The effect of the other variables is more ambiguous and less statistically robust. For instance, trade union density has been found to increase the shadow production in old European countries; in the NMS the relationship is adverse (negative). In principle, both negative and positive effects of trade unionization might be justified. The ability of the unions to prevent firms from offering flexible forms of employment may increase the share of shadow employment. This is consistent with the "insider vs. outsider" theory: unionized workers fight to obtain expensive benefits and thus raise the cost of labor input, making it difficult for employers to offer formal employment. On the other hand, a negative effect may stem from the pressure exerted by trade unions on government to impose harsher penalties for non-contract workers. Unfortunately, our results do not definitively address this issue.

Similarly, large spending on labor market policies has an ambiguous effect. Inefficient provision of labor market policies may in general lead to an expansion of the shadow economy by enabling people and firms to simultaneously take part in LMP programs and in informal activities. In contrast, the shadow economy might be reduced by a better functioning of the labor market and by a more efficient job matching. In the same vein, the minimum wage does not exhibit a significant impact. Conversely, labor taxation has been found to be negatively related to the size of the shadow economy, at least when expressed in occupational terms. This negative effect has been previously reported in several studies that used comparable fiscal variables (for a detailed study see e.g., Friedman et al., 2000). This can be due to the fact that higher labor tax revenues may provide funds for improving the quality of both public services and legal environment, and thus compensate incentives to engaging in the informal sector. Moreover, it should be considered that most of low-income countries examined in this work were characterized by large shadow economies and have lowered taxation recently. Hence, their large informal sector may not be a result of low taxes, but rather of a long socialist experiment characterized, among others, by high taxes. The effect of labor taxation on shadow production is not clear in our results. As a by-product of the analysis it emerges that the lack of relevant data related to the shadow economy and shadow employment for European countries as processed and published by Eurostat is a serious obstacle in examining this issue. 


\section{References}

Acemoglu, D., 2001. Good Jobs versus Bad Jobs. Journal of Labor Economics 19, 11-21. doi:10.1086/209978

Bassanini, A., Nunziata, L., Venn, D., 2009. Job protection legislation and productivity growth in OECD countries. Economic Policy 24, 349-402, doi:10.1111/j.1468-0327.2009.00221.x

Brown, C., Gilroy, C., Kohen, A., 1982. The Effect of the Minimum Wage on Employment and Unemployment. Journal of Economic Literature, 20, 487-528.

Cahuc, P., Michel, P., 1996. Minimum Wage, Unemployment and Growth. European Economic Review 40, 1463-1482. doi:10.1016/00142921(95)00035-6

Card, D., Krueger, A.B., 1995. Myth and Measurement: The New Economics of the Minimum Wage. Princeton University Press, Princeton.

Cazes, S., Nesporova, A., 2003. Labour Markets in Transition: Balancing flexibility and security in Central and Eastern Europe. ILO, Geneva.

Deere, D., Murphy, K.M., Welch, F., 1995. Employment and the 1990-1991 Minimum-Wage Hike. American Economic Review 85, 232-237.

Djankov, S., La Porta, R., Lopez-de-Silanes, F., Shleifer, A., 2002. The Regulation of Entry. Quarterly Journal of Economics 117, 1-37. doi:10.1162/003355302753399436

Djankov, S., Lieberman, I., Mukherjee, J., Nenova, T., 2003. Going Informal: Benefits and Costs. In: Belev, B. (Ed.), The Informal Economy in the EU Accession Countries: Size, Scope, Trends and Challenges to the Process of EU Enlargement. Center for Study of Democracy, Sofia.

Dreher, A., Schneider, F., 2010. Corruption and the shadow economy: an empirical analysis. Public Choice 144, 215-238. doi:10.1007/s11127-009-9513-0

Enste, D.H., 2003. Shadow Economy and Institutional Change in Transition Countries. In: Belev, B. (Ed.): The Informal Economy in the EU Accession Countries: Size, Scope, Trends and Challenges to the Process of EU Enlargement. Center for Study of Democracy, Sofia.

European Commission, 2004. Undeclared Work in an Enlarged Union. An analysis of Undeclared Work: An In-Depth Study of Specific Items. European Commission, Brussels. 
Fialová, K., Schneider, O., 2009. Labor market institutions and their effect on labor market performance in the new EU member countries. Eastern European Economics 47, 59-85. doi:10.2753/EEE0012-8775470303

Freeman, R.B., 2007. Labour Market Institutions Across The World. NBER Working Paper No. 13242. National Bureau of Economic Research, Cambridge, MA.

Friedman, E., Johnson, S., Kaufmann, D., Zoido-Lobatón, P., 2000. Dodging the Grabbing Hand: The Determinants of Unofficial Activity in 69 Countries. Journal of Public Economics 76, 459-493. doi:10.1016/S00472727(99)00093-6

Griffith, R., Macartney, G., 2014. Employment Protection Legislation, Multinational Firms, and Innovation. Review of Economics and Statistics 96, 135-150. doi:10.1162/REST_a_00348

Johnson, S., Kaufmann, D., McMillan, J., Woodruff, Ch., 2000. Why do Firms hide? Bribes and Unofficial Activity After Communism. Journal of Public Economics 76, 495-520. doi:10.1016/S0047-2727(99)00094-8

Johnson, S., Kaufmann, D., Shleifer, A., Goldman, M.I., Weitzman, M.L., 1997. The Unofficial Economy in Transition. Brookings Papers on Economic Activity 1997, 159-239. doi:10.2307/2534688

Johnson, S., Kaufmann, D., Zoido-Lobatón, P., 1998a. Regulatory Discretion and the Unofficial Economy. American Economic Review 88, 387-392.

Johnson, S., Kaufmann, D., Zoido-Lobatón, P., 1998b. Corruption, Public Finances and the Unofficial Economy. World Bank Discussion Paper, World Bank, Washington, DC.

Lehmann, H., Muravyev, A., 2009. How Important Are Labor Market Institutions for Labor Market Performance in Transition Countries? IZA Discussion Paper No. 4673, IZA, Bonn.

Loayza, N.V., 1994. Labor Regulations and the Informal Economy. World Bank Policy Research Working Paper Series, 1335, World Bank, Washington, DC.

Loayza, N.V., Oviedo, A.M., Servén, L., 2005. The Impact of Regulation on Growth and Informality. World Bank Policy Research Working Paper Series, 3623, World Bank, Washington, DC.

Manning, A., 1995. How Do We Know That Real Wages Are Too High? Quarterly Journal of Economics 110, 1111-1125. Margolis, D.N., Navarro, L., Robalino, D.A., 2012. Unemployment Insurance, Job Search and Informal Employment. IZA Discussion Paper No. 6660. 
Martin, J., 2000. What Works among Active Labour Market Policies: Evidence from OECD Countries' Experiences. OECD Economic Studies No.30, OECD, Paris.

Neumark, D., Wascher, W., 2003. Minimum Wages, Labor Market Institutions, and Youth Employment: A Cross-National Analysis. Federal Reserve Finance and Economics Discussion Paper Series, No. 23/2003.

Nickell, S., 1997. Unemployment and Labour Market Rigidities: Europe versus North America. Journal of Economic Perspectives 11, 55-74. doi:10.1257/jep.11.3.55

OECD, 1993. Employment Outlook. Organization for Economic Cooperation and Development, Paris.

OECD, 1997. Employment Outlook. Organization for Economic Cooperation and Development, Paris.

OECD, 1998. Employment Outlook. Organization for Economic Cooperation and Development, Paris.

OECD, 2002. Employment Outlook. Organization for Economic Cooperation and Development, Paris.

OECD, 2004. Employment Outlook. Organization for Economic Cooperation and Development, Paris.

Oviedo, A.M., Thomas, M.R., Karakurum-Ozdemir, K., 2009. Economic Informality: Causes, Costs and Policies - A Literature Survey. World Bank Working Paper No. 167, World Bank, Washington, DC.

Pedersen, S., 2003. The Shadow Economy in Germany, Great Britain and Scandinavia: a measurement based on questionnaire surveys. The Rockwool Foundation Research Unit, Copenhagen.

Perry, G.E., Maloney, W.F., Arias, O.S., Fajnzylber, P., Mason, A.D., Saavedra-Chanduvi, J., 2007. Informality: Exit and Exclusion. World Bank, Washington, DC. doi:10.1596/978-0-8213-7092-6

Rebitzer, J., Taylor, L., 1995. The Consequences of Minimum Wage Laws: Some New Theoretical Ideas. Journal of Public Economics 56, 245-255. doi:10.1016/0047-2727(93)01411-3

Riboud, M., Sánchez-Páramo, C., Silva-Jáuregui, C., 2001. Does Eurosclerosis Matter? Institutional Reform and Labor Market Performance in Central and Eastern European Countries in the 1990s. World Bank, Washington, DC. 
Schaffer, M., Stillman, S., 2006. Xtoverid: Stata module to calculate tests of overidentifying restrictions after xtreg, xtivreg, xtivreg2 and xthtaylor. Statistical Software Components S456779, Boston College Department of Economics, revised 07 Mar 2010.

Schneider, F., 2003. The Size and Development for the Shadow Economies and Shadow Economy Labor Force of 22 Transition and 21 OECD Countries: What Do We Really Know? In: Belev, B. (Ed.), The Informal Economy in the EU Accession Countries: Size, Scope, Trends and Challenges to the Process of EU Enlargement. Center for the Study of Democracy, Sofia.

Schneider, F., Enste, D., 2000. Shadow Economies: Size, Causes, and Consequences. Journal of Economic Literature 38, 77-114. doi:10.1257/jel.38.1.77

Schneider, F., Buehn, A. Montenegro, C., 2010a. New Estimates for the Shadow Economies all over the World. International Economic Journal 24, 443-461. doi:10.1080/10168737.2010.525974

Schneider, F., Buehn, A., Montenegro, C., 2010b. Shadow Economies all over the World: New Estimates for 162 Countries from 1999 to 2007 (Revised Version). World Bank Policy Research Working Paper WPS 5356. World Bank, Washington, DC.

Spiro, P.S., 1993. Evidence of a Post-GST Increase in the Underground Economy. Canadian Tax Journal/ Revue Fiscale Canadienne 41, 247-258.

Stigler, G., 1946. The Economics of Minimum Wage Legislation. American Economic Review, 36, 535-543.

Thomas, J.J., 1992. Informal Economic Activity. LSE Handbooks in Economics, Harvester Wheatsheaf, London.

Venn, D., 2009. Legislation, Collective Bargaining and Enforcement: Updating the OECD Employment Protection Indicators. OECD Social, Employment and Migration Working Papers, No. 89, OECD. doi:10.1787/223334316804

Zahariev, A., 2003. Tax Avoidance in Bulgaria: The Human Capital Approach. In: Belev, B. (Ed.), The Informal Economy in the EU Accession Countries: Size, Scope, Trends and Challenges to the Process of EU Enlargement. Center for the Study of Democracy, Sofia. 


\section{Annex 1: Statistics on the Shadow Economy}

Shadow Production in Europe: Shadow Economy as \% of Official GDP, 1999-2007

\begin{tabular}{|c|c|c|c|c|c|c|c|c|c|c|}
\hline & \multicolumn{9}{|c|}{ Years } & \multirow[t]{2}{*}{ Country average } \\
\hline & 1999 & 2000 & 2001 & 2002 & 2003 & 2004 & 2005 & 2006 & 2007 & \\
\hline Austria & 10.0 & 9.8 & 9.7 & 9.8 & 9.8 & 9.8 & 9.8 & 9.6 & 9.5 & 9.8 \\
\hline Belgium & 22.7 & 22.2 & 22.1 & 22.0 & 22.0 & 21.8 & 21.8 & 21.4 & 21.3 & 21.9 \\
\hline Bulgaria & 37.3 & 36.9 & 36.6 & 36.1 & 35.6 & 34.9 & 34.1 & 33.5 & 32.7 & 35.3 \\
\hline Cyprus & 29.2 & 28.7 & 28.2 & 27.8 & 28.2 & 28.1 & 27.7 & 27.3 & 26.5 & 28.0 \\
\hline Czech Republic & 19.3 & 19.1 & 18.9 & 18.8 & 18.7 & 18.4 & 17.8 & 17.3 & 17.0 & 18.4 \\
\hline Denmark & 18.4 & 18.0 & 18.0 & 18.0 & 18.0 & 17.8 & 17.6 & 17.0 & 16.9 & 17.7 \\
\hline Estonia & - & 32.7 & 32.4 & 32.0 & 31.4 & 31.1 & 30.5 & 29.8 & 29.5 & 31.2 \\
\hline Finland & 18.4 & 18.1 & 17.9 & 17.8 & 17.7 & 17.6 & 17.4 & 17.1 & 17.0 & 17.7 \\
\hline France & 15.7 & 15.2 & 15.0 & 15.1 & 15.0 & 14.9 & 14.8 & 14.8 & 14.7 & 15.0 \\
\hline Germany & 16.4 & 16.0 & 15.9 & 16.1 & 16.3 & 16.1 & 16.0 & 15.6 & 15.3 & 16.0 \\
\hline Greece & 28.5 & 28.7 & 28.2 & 28.0 & 27.4 & 27.1 & 26.9 & 26.4 & 26.5 & 27.5 \\
\hline Hungary & 25.4 & 25.1 & 24.8 & 24.5 & 24.4 & 24.1 & 24.0 & 23.7 & 23.7 & 24.4 \\
\hline Ireland & 16.1 & 15.9 & 15.9 & 15.9 & 16.0 & 15.8 & 15.6 & 15.5 & 15.4 & 15.8 \\
\hline Italy & 27.8 & 27.1 & 26.7 & 26.8 & 27.0 & 27.0 & 27.1 & 26.9 & 26.8 & 27.0 \\
\hline Latvia & 30.8 & 30.5 & 30.1 & 29.8 & 29.4 & 29.0 & 28.4 & 27.7 & 27.2 & 29.2 \\
\hline Lithuania & 33.8 & 33.7 & 33.3 & 32.8 & 32.0 & 31.7 & 31.0 & 30.4 & 29.7 & 32.0 \\
\hline Luxembourg & 10.0 & 9.8 & 9.8 & 9.8 & 9.8 & 9.8 & 9.7 & 9.6 & 9.4 & 9.7 \\
\hline Malta & 27.4 & 27.1 & 27.3 & 27.3 & 27.5 & 27.6 & 27.3 & 27.0 & 26.5 & 27.2 \\
\hline Netherlands & 13.3 & 13.1 & 13.1 & 13.2 & 13.3 & 13.2 & 13.2 & 13.2 & 13.0 & 13.2 \\
\hline Norway & 19.2 & 19.1 & 19.0 & 19.0 & 19.0 & 18.5 & 18.5 & 18.2 & 18.0 & 18.7 \\
\hline Poland & 27.7 & 27.6 & 27.7 & 27.7 & 27.5 & 27.3 & 26.9 & 26.4 & 26.0 & 27.2 \\
\hline Portugal & 23.0 & 22.7 & 22.6 & 22.7 & 23.0 & 23.1 & 23.3 & 23.2 & 23.0 & 23.0 \\
\hline Romania & 34.3 & 34.4 & 33.7 & 33.5 & 32.8 & 32.0 & 31.7 & 30.7 & 30.2 & 32.6 \\
\hline Slovak Republic & 18.9 & 18.9 & 18.8 & 18.6 & 18.3 & 18.1 & 17.6 & 17.2 & 16.8 & 18.1 \\
\hline Slovenia & 27.3 & 27.1 & 26.7 & 26.6 & 26.4 & 26.2 & 25.8 & 25.3 & 24.7 & 26.2 \\
\hline Spain & 23.0 & 22.7 & 22.4 & 22.4 & 22.4 & 22.5 & 22.4 & 22.4 & 22.2 & 22.5 \\
\hline Sweden & 19.6 & 19.2 & 19.1 & 19.0 & 18.7 & 18.5 & 18.6 & 18.2 & 17.9 & 18.8 \\
\hline United Kingdom & 12.8 & 12.7 & 12.6 & 12.6 & 12.5 & 12.4 & 12.4 & 12.3 & 12.2 & 12.5 \\
\hline
\end{tabular}

Source: Schneider et al. (2010a) 
Informal Employment in Europe: Share of Labor Force Not Contributing to Pension System (\%) Adjusted for the Unemployment Rate, 2007

\begin{tabular}{|c|c|c|c|}
\hline & $\begin{array}{l}\text { Labor force without pension system } \\
\text { contributions (\%) }\end{array}$ & $\begin{array}{c}\text { Unemployment rate } \\
\text { (\%) }\end{array}$ & $\begin{array}{l}\text { Labor force without pension system contributions (\%), } \\
\text { adjusted for unemployment rate }\end{array}$ \\
\hline Austria & 11.06 & 4.40 & 6.66 \\
\hline Belgium & 21.49 & 7.50 & 13.99 \\
\hline Bulgaria & n.a. & 6.90 & n.a. \\
\hline Cyprus & 20.26 & 4.00 & 16.26 \\
\hline Czech Republic & 15.17 & 5.30 & 9.87 \\
\hline Denmark & 5.95 & 3.80 & 2.15 \\
\hline Estonia & 10.34 & 4.70 & 5.64 \\
\hline Finland & 10.85 & 6.90 & 3.95 \\
\hline France & n.a. & 8.40 & n.a. \\
\hline Germany & n.a. & 8.40 & n.a. \\
\hline Greece & 38.60 & 8.30 & 30.30 \\
\hline Hungary & 14.45 & 7.40 & 7.05 \\
\hline Ireland & 23.32 & 4.60 & 18.72 \\
\hline Italy & 23.57 & 6.10 & 17.47 \\
\hline Latvia & 15.85 & 6.00 & 9.85 \\
\hline Lithuania & n.r. & 4.30 & n.r. \\
\hline Luxembourg & n.r. & 4.20 & n.r. \\
\hline Malta & n.a. & 6.40 & n.a. \\
\hline Netherlands & 6.79 & 3.20 & 3.59 \\
\hline Norway & 6.44 & 2.50 & 3.94 \\
\hline Poland & n.r. & 9.60 & n.r. \\
\hline Portugal & n.r. & 8.10 & n.r. \\
\hline Romania & n.a. & 6.40 & n.a. \\
\hline Slovak Republic & 16.53 & 11.10 & 5.43 \\
\hline Slovenia & 10.90 & 4.90 & 6.00 \\
\hline Spain & 24.00 & 8.30 & 15.70 \\
\hline Sweden & 6.88 & 6.10 & 0.78 \\
\hline United Kingdom & n.r. & 5.30 & n.r. \\
\hline
\end{tabular}

Note: n.a. - data not available, n.r. - data not reliable due to divergent development in time or too low value compared with the unemployment rate.

Source: Eurostat: European Union-Statistics on Income and Living Conditions (EU-SILC), own calculations 
Informal Employment in Europe: Share of Labor Force Working in Small Firms or Being Self-Employed (\%), 2006-2007

\begin{tabular}{|c|c|c|c|c|}
\hline & \multicolumn{2}{|c|}{$\begin{array}{l}\text { Workers in firms with } \\
\text { fewer than } 10 \\
\text { employees } \\
\text { (\% of labor force) }\end{array}$} & \multicolumn{2}{|c|}{$\begin{array}{l}\text { Self-employed } \\
\text { (\% of labor force) }\end{array}$} \\
\hline & 2006 & 2007 & 2006 & 2007 \\
\hline Austria & 30.09 & 30.28 & 11.48 & 11.43 \\
\hline Belgium & 19.84 & 19.38 & 12.42 & 12.52 \\
\hline Bulgaria & 18.47 & 18.66 & 10.80 & 10.47 \\
\hline Cyprus & 37.82 & 38.89 & 18.43 & 17.90 \\
\hline Czech Republic & 23.54 & 22.92 & 14.36 & 14.74 \\
\hline Denmark & 21.15 & 20.86 & 8.04 & 8.18 \\
\hline Estonia & 18.21 & 18.17 & 7.37 & 8.32 \\
\hline Finland & 28.56 & 28.41 & 11.31 & 11.64 \\
\hline France & 25.41 & 25.74 & 9.37 & 9.24 \\
\hline Germany & 21.17 & 20.94 & 10.10 & 10.02 \\
\hline Greece & 46.60 & 47.24 & 27.20 & 26.91 \\
\hline Hungary & 25.26 & 26.57 & 11.27 & 11.06 \\
\hline Ireland & 27.31 & n.a. & 15.17 & 15.65 \\
\hline Italy & 31.83 & 31.98 & 22.90 & 22.78 \\
\hline Latvia & 25.52 & 32.57 & 9.33 & 8.62 \\
\hline Lithuania & 16.97 & 15.86 & 12.58 & 11.42 \\
\hline Luxembourg & 15.43 & 17.95 & 7.29 & 6.78 \\
\hline Malta & n.a. & n.a. & n.a. & n.a. \\
\hline Netherlands & 17.24 & 17.38 & 11.88 & 12.05 \\
\hline Norway & 95.05 & 96.35 & 7.89 & 7.44 \\
\hline Poland & 20.36 & 21.34 & 17.14 & 17.39 \\
\hline Portugal & 33.12 & 33.59 & 21.47 & 21.58 \\
\hline Romania & 23.89 & 23.80 & 19.20 & 19.82 \\
\hline Slovak Republic & 27.70 & 27.66 & 10.90 & 11.41 \\
\hline Slovenia & 22.04 & 20.78 & 10.65 & 10.57 \\
\hline Spain & 33.77 & 32.98 & 15.12 & 15.26 \\
\hline Sweden & 21.75 & 21.70 & 9.69 & 9.68 \\
\hline United Kingdom & 19.39 & 19.59 & 12.06 & 12.28 \\
\hline
\end{tabular}

Note: n.a. - data not available

Source: Eurostat: Labor Force Surveys, own calculations 
Informal Employment in Europe: Share of Labor Force Employed on Temporary Contract Basis or Without a Legal Contract (\%), 2001-2007

\begin{tabular}{|c|c|c|c|c|c|c|c|c|}
\hline & \multicolumn{7}{|c|}{ Years } & \multirow{2}{*}{$\begin{array}{l}\text { Country } \\
\text { average }\end{array}$} \\
\hline & 2001 & 2002 & 2003 & 2004 & 2005 & 2006 & 2007 & \\
\hline Austria & 7.05 & 6.43 & 6.25 & 8.23 & 7.88 & 7.81 & 7.62 & 7.32 \\
\hline Belgium & 7.46 & 6.45 & 7.25 & 7.41 & 7.51 & 7.41 & 7.37 & 7.27 \\
\hline Bulgaria & 5.58 & 4.95 & 5.33 & 6.64 & 5.46 & 5.40 & 4.50 & 5.41 \\
\hline Czech Republic & 6.90 & 6.95 & 7.62 & 7.92 & 7.26 & 7.30 & 7.20 & 7.31 \\
\hline Denmark & 8.48 & 8.05 & 8.59 & 8.96 & 8.97 & 8.08 & 7.95 & 8.44 \\
\hline Estonia & 2.65 & 2.08 & 2.73 & 2.72 & 2.45 & 2.53 & 1.94 & 2.44 \\
\hline Finland & 15.58 & 15.01 & 15.59 & 14.95 & 15.87 & 15.68 & 14.39 & 15.30 \\
\hline France & 13.31 & 12.67 & 11.92 & 11.61 & 12.61 & 12.91 & 13.20 & 12.60 \\
\hline Germany & .. & 10.87 & 11.01 & 11.17 & 12.60 & 12.29 & 12.83 & 11.80 \\
\hline Greece & 8.12 & 7.16 & 6.91 & 7.88 & 7.52 & 6.79 & 6.99 & 7.34 \\
\hline Hungary & 6.44 & 6.47 & 6.47 & 5.92 & 6.07 & 5.88 & 6.39 & 6.23 \\
\hline Ireland & 3.79 & 4.00 & 3.85 & 2.79 & n.a. & n.a. & 7.47 & 4.38 \\
\hline Italy & 6.88 & 7.16 & 6.92 & 8.55 & 8.98 & 9.67 & 9.77 & 8.28 \\
\hline Latvia & 6.06 & 10.05 & 8.24 & 7.94 & 7.43 & 6.33 & 3.73 & 7.11 \\
\hline Lithuania & 5.26 & 5.98 & 6.38 & 5.37 & 4.61 & 3.80 & 3.06 & 4.92 \\
\hline Luxembourg & 4.04 & 3.95 & 2.88 & 4.40 & 4.86 & 5.59 & 6.33 & 4.58 \\
\hline Netherlands & 12.64 & 12.66 & 12.81 & 12.80 & 13.55 & 13.57 & 14.70 & 13.25 \\
\hline Norway & 8.39 & 9.38 & 8.78 & 9.41 & 8.82 & 9.68 & 9.38 & 9.12 \\
\hline Poland & 8.60 & 11.13 & 13.82 & 16.58 & 19.05 & 20.65 & 21.59 & 15.92 \\
\hline Portugal & 14.41 & 15.69 & 15.03 & 14.72 & 14.51 & 15.53 & 16.88 & 15.25 \\
\hline Romania & 1.61 & 0.55 & 1.28 & 1.79 & 1.55 & 1.20 & 1.06 & 1.29 \\
\hline Slovak Republic & 4.60 & 4.37 & 4.49 & 4.82 & 4.35 & 4.47 & 4.42 & 4.50 \\
\hline Slovenia & 10.83 & 12.33 & 11.75 & 15.20 & 14.76 & 14.47 & 15.57 & 13.56 \\
\hline Spain & 25.61 & 25.90 & 25.98 & 26.25 & 27.28 & 26.94 & 24.99 & 26.14 \\
\hline Sweden & 14.08 & 13.98 & 14.14 & 14.04 & 11.73 & 12.87 & 13.12 & 13.42 \\
\hline United Kingdom & 5.98 & 5.45 & 5.15 & 5.06 & 4.87 & 4.93 & 5.08 & 5.22 \\
\hline
\end{tabular}

Note: n.a. - data not available

Source: Eurostat: Labor Force Surveys, own calculations 
Comparison of Indicators: Shadow Production (\% of GDP) vs. Shadow Employment in Europe (Share of Labor Force Not Contributing to Pension System Adjusted for the Unemployment Rate, \%), 2007

\begin{tabular}{|l|r|r|r|r|r|}
\hline & $\begin{array}{c}\text { Labor force without } \\
\text { pension system } \\
\text { contributions (\%) } \\
\text { (CONTRIB) }\end{array}$ & $\begin{array}{c}\text { Shadow economy } \\
\text { (\% GDP) } \\
\text { (SHEC) }\end{array}$ & $\begin{array}{c}\text { Ranking } \\
\text { CONTRIB }\end{array}$ & $\begin{array}{c}\text { Ranking } \\
\text { SHEC }\end{array}$ & $\begin{array}{c}\text { Difference } \\
\text { in ranking }\end{array}$ \\
\hline Austria & 6.7 & 9.5 & 9 & 1 & 8 \\
\hline Belgium & 14.0 & 21.3 & 13 & 10 & 3 \\
\hline Cyprus & 16.3 & 26.5 & 15 & 14 & 1 \\
\hline Czech Republic & 9.9 & 17.0 & 12 & 6 & 6 \\
\hline Denmark & 2.1 & 16.9 & 2 & 5 & -3 \\
\hline Estonia & 5.6 & 29.5 & 7 & 18 & -11 \\
\hline Finland & 4.0 & 17.0 & 5 & 6 & -1 \\
\hline Greece & 30.3 & 26.5 & 18 & 14 & 4 \\
\hline Hungary & 7.0 & 23.7 & 10 & 12 & -2 \\
\hline Ireland & 18.7 & 15.4 & 17 & 3 & 14 \\
\hline Italy & 17.5 & 26.8 & 16 & 16 & 0 \\
\hline Latvia & 9.9 & 27.2 & 11 & 17 & -6 \\
\hline Netherlands & 3.6 & 13.0 & 3 & 2 & 1 \\
\hline Norway & 3.9 & 18.0 & 4 & 9 & -5 \\
\hline Slovak Republic & 5.4 & 16.8 & 6 & 4 & 2 \\
\hline Slovenia & 0.0 & 24.7 & 8 & 13 & -5 \\
\hline Spain & 15.7 & 17.9 & 1 & 8 & 3 \\
\hline Sweden & & 22.2 & 11 & -7 \\
\hline
\end{tabular}

Note: countries with absolute value of difference in ranking higher than 5 marked red.

Source: Schneider et al. (2010a), Eurostat: European Union-Statistics on Income and Living Conditions (EUSILC), own calculations 


\section{Annex 2: Variables Used in the Analysis - Defini- tions and Data Sources}

\begin{tabular}{|c|c|c|c|c|c|}
\hline \multicolumn{6}{|c|}{ SHADOW ECONOMY } \\
\hline Name & Abbreviation & Source & Years & Sample & Description \\
\hline $\begin{array}{l}\text { Shadow } \\
\text { economy as } \\
\text { percentage } \\
\text { share on } \\
\text { official GDP }\end{array}$ & SHEC & $\begin{array}{l}\text { Schneider } \\
\text { et al. } \\
(2010 a)\end{array}$ & $\begin{array}{l}1999- \\
2007\end{array}$ & $B S, E S$ & Estimations based on a Multiple Indicators Multiple Causes (MIMIC) model approach \\
\hline $\begin{array}{l}\text { Share of labor } \\
\text { force not } \\
\text { contributing to } \\
\text { pension system }\end{array}$ & CONTRIB & $\begin{array}{l}\text { Eurostat: } \\
\text { European } \\
\text { Union- } \\
\text { Statistics } \\
\text { on Income } \\
\text { and Living } \\
\text { Conditions } \\
\text { (EU-SILC) } \\
\end{array}$ & 2007 & ES & $\begin{array}{l}\text { Share of labor force not contributing to pension system (both private and public) } \\
\text { adjusted for the unemployment rate (\%) }\end{array}$ \\
\hline $\begin{array}{l}\text { Share of labor } \\
\text { force working } \\
\text { in small firms }\end{array}$ & LESS10 & $\begin{array}{l}\text { Eurostat: } \\
\text { Labor } \\
\text { Force } \\
\text { Survey } \\
\text { (LFS) }\end{array}$ & $\begin{array}{l}2006- \\
2007\end{array}$ & $B S, E S$ & Share of labor force working in small firms (under 10 employees; \%) \\
\hline $\begin{array}{l}\text { Share of labor } \\
\text { force being } \\
\text { self-employed }\end{array}$ & SELFEMPL & $\begin{array}{l}\text { Eurostat: } \\
\text { Labor } \\
\text { Force } \\
\text { Survey } \\
\text { (LFS) } \\
\end{array}$ & $\begin{array}{l}2006- \\
2007\end{array}$ & $B S, E S$ & Share of labor force being self-employed (\%) \\
\hline $\begin{array}{l}\text { Share of labor } \\
\text { force employed } \\
\text { without a legal } \\
\text { contract }\end{array}$ & CONTRACT & $\begin{array}{l}\text { Eurostat: } \\
\text { Labor } \\
\text { Force } \\
\text { Survey } \\
\text { (LFS) }\end{array}$ & $\begin{array}{l}2001- \\
2007\end{array}$ & BS, ES & $\begin{array}{l}\text { Share of labor force employed on temporary contract basis or without a legal contract } \\
\text { (\%) }\end{array}$ \\
\hline
\end{tabular}




\begin{tabular}{|c|c|c|c|c|c|}
\hline \multicolumn{6}{|c|}{ LABOR MARKET INSTITUTIONS } \\
\hline Name & Abbreviation & Source & Years & Sample & Description \\
\hline $\begin{array}{l}\text { Employment } \\
\text { protection } \\
\text { legislation }\end{array}$ & EPL2 & OECD & $\begin{array}{l}2000- \\
2007\end{array}$ & BS, ES & $\begin{array}{l}\text { Employment protection legislation index, version 2, higher index reflects more rigid } \\
\text { legislation. }\end{array}$ \\
\hline Minimum wage & MWSH & OECD & $\begin{array}{l}2000- \\
2007\end{array}$ & BS & $\begin{array}{l}\text { Minimum wage: share on median wage in the economy, cluster variable }(0-3) \text {, higher } \\
\text { score means greater burden of minimum wage ( } 0 \text { in case statutory minimum wage not } \\
\text { implemented). }\end{array}$ \\
\hline $\begin{array}{l}\text { Trade union } \\
\text { membership }\end{array}$ & TU & OECD & $\begin{array}{l}2000- \\
2007\end{array}$ & BS, ES & Trade union membership, share of all workers (\%). \\
\hline $\begin{array}{l}\text { Total tax wedge } \\
\text { on labor }\end{array}$ & TAXW & OECD & $\begin{array}{l}2000- \\
2007\end{array}$ & BS, ES & $\begin{array}{l}\text { Total tax wedge on labor: average personal income tax and social security contribution } \\
\text { rates on gross labor income, } 100 \% \text { of average wage. The combined central and sub-central } \\
\text { government income tax plus employee and employer social security contribution taxes, as } \\
\text { a percentage of labor costs defined as gross wage earnings plus employer social security } \\
\text { contributions. The tax wedge includes cash transfers. }\end{array}$ \\
\hline $\begin{array}{l}\text { Active labor } \\
\text { market policy } \\
\text { expenditure }\end{array}$ & LMPA & OECD & $\begin{array}{l}2000- \\
2007\end{array}$ & $B S$, ES & $\begin{array}{l}\text { Active labor market policy expenditure (categories 20-70), \% GDP per percentage point of } \\
\text { unemployment }\end{array}$ \\
\hline $\begin{array}{l}\text { Passive labor } \\
\text { market policy } \\
\text { expenditure }\end{array}$ & LMPP & OECD & $\begin{array}{l}2000- \\
2007\end{array}$ & BS & $\begin{array}{l}\text { Passive labor market policy expenditure (categories } 80-90 \text { ), \% GDP per percentage point } \\
\text { of unemployment }\end{array}$ \\
\hline Minimum wage & MWPPS & Eurostat & $\begin{array}{l}2006- \\
2007\end{array}$ & ES & $\begin{array}{l}\text { Minimum wage in PPS, cluster variable (0-4), higher score means greater burden of } \\
\text { minimum wage ( } 0 \text { in case statutory minimum wage not implemented). }\end{array}$ \\
\hline $\begin{array}{l}\text { Passive labor } \\
\text { market policy } \\
\text { expenditure }\end{array}$ & LMPP & Eurostat & $\begin{array}{l}2006- \\
2007\end{array}$ & ES & $\begin{array}{l}\text { Passive labor market policy expenditure (categories } 80-90 \text { ), \% GDP per percentage point } \\
\text { of unemployment. }\end{array}$ \\
\hline $\begin{array}{l}\text { Employment } \\
\text { protection } \\
\text { legislation }\end{array}$ & EPL2 & IZA & 2007 & ES & $\begin{array}{l}\text { Employment protection legislation index, version 2, higher index reflects more rigid } \\
\text { legislation. }\end{array}$ \\
\hline $\begin{array}{l}\text { Trade union } \\
\text { membership }\end{array}$ & TU & IZA & 2007 & ES & Trade union membership, share of all workers (\%). \\
\hline $\begin{array}{l}\text { Total tax wedge } \\
\text { on labor }\end{array}$ & TAXW & IZA & 2007 & ES & $\begin{array}{l}\text { Total tax wedge on labor: average personal income tax and social security contribution } \\
\text { rates on gross labor income, } 100 \% \text { of average wage. The combined central and sub-central } \\
\text { government income tax plus employee and employer social security contribution taxes, as } \\
\text { a percentage of labor costs defined as gross wage earnings plus employer social security } \\
\text { contributions. The tax wedge includes cash transfers. }\end{array}$ \\
\hline $\begin{array}{l}\text { Active labor } \\
\text { market policy } \\
\text { expenditure }\end{array}$ & LMPA & IZA & 2007 & ES & $\begin{array}{l}\text { Active labor market policy expenditure (categories } 20-70 \text { ), \% GDP per percentage point of } \\
\text { unemployment. }\end{array}$ \\
\hline
\end{tabular}




\begin{tabular}{|c|c|c|c|c|c|}
\hline \multicolumn{6}{|c|}{ CONTROL VARIABLES ON ECONOMIC-POLITICAL ENVIRONMENT } \\
\hline Name & Abbreviation & Source & Years & Sample & Description \\
\hline $\begin{array}{l}\text { GDP per } \\
\text { capita }\end{array}$ & GDPPC & World Bank & $\begin{array}{l}2000- \\
2007\end{array}$ & BS, ES & Logarithm GDP per capita, purchasing power parities \\
\hline $\begin{array}{l}\text { Life } \\
\text { expectancy } \\
\text { at birth }\end{array}$ & LEXP & Eurostat & $\begin{array}{l}2000- \\
2007\end{array}$ & BS, ES & $\begin{array}{l}\text { The indicator represents the mean number of years still to be lived by a person who } \\
\text { has reached a certain exact age, if subjected throughout the rest of his or her life to } \\
\text { the current mortality conditions. }\end{array}$ \\
\hline $\begin{array}{l}\text { Fiscal } \\
\text { freedom }\end{array}$ & FISF & $\begin{array}{l}\text { Heritage } \\
\text { Foundation }\end{array}$ & $\begin{array}{l}2000- \\
2007\end{array}$ & $B S, E S$ & $\begin{array}{l}\text { Measure of the tax burden imposed by government. Includes both the direct tax } \\
\text { burden on individual and corporate incomes and the overall amount of tax revenue. } \\
\text { Composed of three quantitative factors: 1) top tax rate on individual income, 2) top } \\
\text { tax rate on corporate income, 3) total tax revenue as a percentage of GDP. }\end{array}$ \\
\hline $\begin{array}{l}\text { Business } \\
\text { freedom }\end{array}$ & BUSF & $\begin{array}{l}\text { Heritage } \\
\text { Foundation }\end{array}$ & $\begin{array}{l}2000- \\
2007\end{array}$ & BS, ES & $\begin{array}{l}\text { Quantitative measure of the ability to start, operate, and close a business that } \\
\text { represents the overall burden of regulation as well as the efficiency of government in } \\
\text { the regulatory process. The business freedom score for each country is a number } \\
\text { between } 0 \text { and 100, with } 100 \text { equaling the freest business environment. The score is } \\
\text { based on } 10 \text { factors, all weighted equally, using data from the World Bank's Doing } \\
\text { Business study. }\end{array}$ \\
\hline $\begin{array}{l}\text { Control of } \\
\text { corruption }\end{array}$ & CORR & $\begin{array}{l}\text { World Bank, } \\
\text { Worldwide } \\
\text { Governance } \\
\text { Indicators }\end{array}$ & $\begin{array}{l}2000- \\
2007\end{array}$ & BS, ES & $\begin{array}{l}\text { The measure shows the extent to which public power is exercised for private gain, } \\
\text { including petty and grand forms of corruption, as well as "capture" of the state by } \\
\text { elites and private interests. The higher the score, the better control of corruption. } \\
\text { Data for } 2001 \text { interpolated from years } 2000 \text { and } 2002 \text {. }\end{array}$ \\
\hline $\begin{array}{l}\text { Regulatory } \\
\text { quality }\end{array}$ & REGQUAL & $\begin{array}{l}\text { World Bank, } \\
\text { Worldwide } \\
\text { Governance } \\
\text { Indicators }\end{array}$ & $\begin{array}{l}2000- \\
2007\end{array}$ & BS, ES & $\begin{array}{l}\text { Measure of the ability of the government to formulate and implement sound policies } \\
\text { and regulations that permit and promote private sector development. The higher the } \\
\text { score, the better regulatory quality. Data for } 2001 \text { interpolated from years } 2000 \text { and } \\
2002 \text {. }\end{array}$ \\
\hline
\end{tabular}

\section{Annex 3: Detailed Description of Applied Regres- sion Models}

Model Shadow economy, Basic sample Dependent variable: shadow economy as percentage share on overall official GDP (SHEC) Explanatory variables:

\begin{tabular}{|l|l|}
\hline EPL2 & OECD index, version 2 \\
\hline MWSH & OECD, share of minimum wage on median wage in the economy \\
\hline TU & OECD, Trade union membership, \% wage earners \\
\hline TAXW & OECD, Total tax wedge on labor \\
\hline LMPA & OECD, Active LMP expenditure, \% GDP per percentage point of unemployment \\
\hline LMPP & OECD, Passive LMP expenditure, \% GDP per percentage point of unemployment \\
\hline LEXP & Eurostat, Life expectancy at birth \\
\hline FISF & Heritage Foundation, Fiscal freedom \\
\hline BUSF & Heritage Foundation, Business freedom \\
\hline CORR & WB, Control of corruption \\
\hline REGQUAL & WB, Regulatory quality \\
\hline
\end{tabular}

Data sample: 2000-2007, S1 (15 old EU members, 4 NMS) 
Model Shadow economy, Extended sample Dependent variable: shadow economy as percentage share on overall official GDP (SHEC) Explanatory variables:

\begin{tabular}{|l|l|}
\hline EPL2 & OECD index, version 2 \\
\hline MWPPS & Eurostat, share of minimum wage on median wage in the economy \\
\hline TU & OECD, Trade union membership, \% wage earners \\
\hline TAXW & OECD, Total tax wedge on labor \\
\hline LMPA & OECD, Active LMP expenditure, \% GDP per percentage point of unemployment \\
\hline LMPP & OECD, Passive LMP expenditure, \% GDP per percentage point of unemployment \\
\hline LEXP & Eurostat, Life expectancy at birth \\
\hline FISF & Heritage Foundation, Fiscal freedom \\
\hline BUSF & Heritage Foundation, Business freedom \\
\hline CORR & WB, Control of corruption \\
\hline REGQUAL & WB, Regulatory quality \\
\hline
\end{tabular}

Data sample: 2003 and 2007, S3 (16 old EU members, 10 NMS)

Model Non-contributing to pension system, Basic sample Dependent variable: share of labor force not contributing to the pension system - both public and private (CONTRIB) Data sample: 2007, S1 - 9 countries only, LACK OF DATA FOR REGRESSION ESTIMATION

Model Non-contributing to pension system, Extended sample Dependent variable: share of labor force not contributing to the pension system - both public and private (CONTRIB) Explanatory variables:

\begin{tabular}{|l|l|}
\hline EPL2 & OECD index, version 2 \\
\hline MWPPS & Eurostat, share of minimum wage on median wage in the economy \\
\hline TU & OECD, Trade union membership, \% wage earners \\
\hline TAXW & OECD, Total tax wedge on labor \\
\hline LMPA & OECD, Active LMP expenditure, \% GDP per percentage point of unemployment \\
\hline LMPP & OECD, Passive LMP expenditure, \% GDP per percentage point of unemployment \\
\hline GDPPC & WB, GDP per capita, purchasing power parities \\
\hline FISF & Heritage Foundation, Fiscal freedom \\
\hline BUSF & Heritage Foundation, Business freedom \\
\hline CORR & WB, Control of corruption \\
\hline REGQUAL & WB, Regulatory quality \\
\hline
\end{tabular}

Data sample: 2003 and 2007, S3 (11 old EU members, 6 NMS)

Model Small business employment, Basic sample Dependent variable: share of labor force employed in small firms with fewer than 10 employees (LESS10) Explanatory variables: 


\begin{tabular}{|l|l|}
\hline EPL2 & OECD index, version 2 \\
\hline MWSH & OECD, share of minimum wage on median wage in the economy \\
\hline TU & OECD, Trade union membership, \% wage earners \\
\hline TAXW & OECD, Total tax wedge on labor \\
\hline LMPA & OECD, Active LMP expenditure, \% GDP per percentage point of unemployment \\
\hline LMPP & OECD, Passive LMP expenditure, \% GDP per percentage point of unemployment \\
\hline GDPPC & WB, GDP per capita, purchasing power parities \\
\hline FISF & Heritage Foundation, Fiscal freedom \\
\hline BUSF & Heritage Foundation, Business freedom \\
\hline CORR & WB, Control of corruption \\
\hline REGQUAL & WB, Regulatory quality \\
\hline
\end{tabular}

Data sample: 2000-2007, S1 (15 old EU members, 4 NMS)

Model Small business employment, Extended sample Dependent variable: share of labor force employed in small firms with fewer than 10 employees (LESS10) Explanatory variables:

\begin{tabular}{|l|l|}
\hline EPL2 & OECD index, version 2 \\
\hline MWPPS & Eurostat, share of minimum wage on median wage in the economy \\
\hline TU & OECD, Trade union membership, \% wage earners \\
\hline TAXW & OECD, Total tax wedge on labor \\
\hline LMPA & OECD, Active LMP expenditure, \% GDP per percentage point of unemployment \\
\hline LMPP & OECD, Passive LMP expenditure, \% GDP per percentage point of unemployment \\
\hline GDPPC & WB, GDP per capita, purchasing power parities \\
\hline FISF & Heritage Foundation, Fiscal freedom \\
\hline BUSF & Heritage Foundation, Business freedom \\
\hline CORR & WB, Control of corruption \\
\hline REGQUAL & WB, Regulatory quality \\
\hline
\end{tabular}

Data sample: 2003 and 2007, S3 (15 old EU members, 9 NMS)

Model Self-employed, Basic sample Dependent variable: share of labor force being self-employed (SELFEMPL) Explanatory variables:

\begin{tabular}{|l|l|}
\hline EPL2 & OECD index, version 2 \\
\hline MWSH & OECD, share of minimum wage on median wage in the economy \\
\hline TU & OECD, Trade union membership, \% wage earners \\
\hline TAXW & OECD, Total tax wedge on labor \\
\hline LMPA & OECD, Active LMP expenditure, \% GDP per percentage point of unemployment \\
\hline LMPP & OECD, Passive LMP expenditure, \% GDP per percentage point of unemployment \\
\hline GDPPC & WB, GDP per capita, purchasing power parities \\
\hline FISF & Heritage Foundation, Fiscal freedom \\
\hline BUSF & Heritage Foundation, Business freedom \\
\hline CORR & WB, Control of corruption \\
\hline REGQUAL & WB, Regulatory quality \\
\hline
\end{tabular}

Data sample: 2000-2007, S1 (15 old EU members, 4 NMS)

Model Self-employed, Extended sample Dependent variable: share of labor force being self-employed (SELFEMPL) Explanatory variables: 


\begin{tabular}{|l|l|}
\hline EPL2 & OECD index, version 2 \\
\hline MWPPS & Eurostat, share of minimum wage on median wage in the economy \\
\hline TU & OECD, Trade union membership, \% wage earners \\
\hline TAXW & OECD, Total tax wedge on labor \\
\hline LMPA & OECD, Active LMP expenditure, \% GDP per percentage point of unemployment \\
\hline LMPP & OECD, Passive LMP expenditure, \% GDP per percentage point of unemployment \\
\hline GDPPC & WB, GDP per capita, purchasing power parities \\
\hline FISF & Heritage Foundation, Fiscal freedom \\
\hline BUSF & Heritage Foundation, Business freedom \\
\hline CORR & WB, Control of corruption \\
\hline REGQUAL & WB, Regulatory quality \\
\hline
\end{tabular}

Data sample: 2003 and 2007, S3 (16 old EU members, 9 NMS))

Model Employed without a contract, Basic sample Dependent variable: share of labor force without a legal written contract (CONTRACT) Explanatory variables:

\begin{tabular}{|l|l|}
\hline EPL2 & OECD index, version 2 \\
\hline MWSH & OECD, share of minimum wage on median wage in the economy \\
\hline TU & OECD, Trade union membership, \% wage earners \\
\hline TAXW & OECD, Total tax wedge on labor \\
\hline LMPA & OECD, Active LMP expenditure, \% GDP per percentage point of unemployment \\
\hline LMPP & OECD, Passive LMP expenditure, \% GDP per percentage point of unemployment \\
\hline GDPPC & WB, GDP per capita, purchasing power parities \\
\hline FISF & Heritage Foundation, Fiscal freedom \\
\hline BUSF & Heritage Foundation, Business freedom \\
\hline CORR & WB, Control of corruption \\
\hline REGQUAL & WB, Regulatory quality \\
\hline
\end{tabular}

Data sample: 2000-2007, S1 (15 old EU members, 4 NMS)

Model Non-contract employment, Extended sample Dependent variable: share of labor force without a legal written contract (CONTRACT) Explanatory variables:

\begin{tabular}{|l|l|}
\hline EPL2 & OECD index, version 2 \\
\hline MWPPS & Eurostat, share of minimum wage on median wage in the economy \\
\hline TU & OECD, Trade union membership, \% wage earners \\
\hline TAXW & OECD, Total tax wedge on labor \\
\hline LMPA & OECD, Active LMP expenditure, \% GDP per percentage point of unemployment \\
\hline LMPP & OECD, Passive LMP expenditure, \% GDP per percentage point of unemployment \\
\hline GDPPC & WB, GDP per capita, purchasing power parities \\
\hline FISF & Heritage Foundation, Fiscal freedom \\
\hline BUSF & Heritage Foundation, Business freedom \\
\hline CORR & WB, Control of corruption \\
\hline REGQUAL & WB, Regulatory quality \\
\hline
\end{tabular}

Data sample: 2003 and 2007, S3 (16 old EU members, 9 NMS) 